\title{
WAS EXPANSIONARY MONETARY \\ POLICY FEASIBLE DURING THE GREAT CONTRACTION? \\ AN EXAMINATION OF THE GOLD \\ STANDARD CONSTRAINT
}

\author{
Michael D. Bordo \\ Ehsan U. Choudhri \\ Anna J. Schwartz
}

Working Paper 7125

http://www.nber.org/papers/w7125

\author{
NATIONAL BUREAU OF ECONOMIC RESEARCH \\ 1050 Massachusetts Avenue \\ Cambridge, MA 02138 \\ May 1999
}

For helpful comments on earlier drafts, we thank Bill Dewald, Barry Eichengreen, Peter Kenen, Don Mathieson, Christina Romer, Michael Woodford, and participants at seminars at New York University, Princeton, University of California at Berkeley, Rutgers, the IMF, the Federal Reserve Bank of St. Louis, and the NBER Monetary Economics program meeting, April 1999. The views expressed herein are those of the authors and do not necessarily reflect the views of the National Bureau of Economic Research.

( 1999 by Michael D. Bordo, Ehsan U. Choudhri, and Anna J. Schwartz. All rights reserved. Short sections of text, not to exceed two paragraphs, may be quoted without explicit permission provided that full credit, including ${ }^{\circ}$ notice, is given to the source. 
Was Expansionary Monetary Policy Feasible

During the Great Contraction? An Examination

of the Gold Standard Constraint

Michael D. Bordo, Ehsan U. Choudhri,

and Anna J. Schwartz

NBER Working Paper No. 7125

May 1999

JEL No. E5, F3

\section{ABSTRACT}

The recent consensus view, that the gold standard was the leading cause of the worldwide Great Depression 1929-33, stems from two propositions: (1) Under the gold standard, deflationary shocks were transmitted between countries and, (2) for most countries, continued adherence to gold prevented monetary authorities from offsetting banking panics and blocked their recoveries. In this paper we contend that the second proposition applies only to small open economies with limited gold reserves. This was not the case for the US, the largest country in the world, holding massive gold reserves. The US was not constrained from using expansionary policy to offset banking panics, deflation, and declining economic activity.

Simulations, based on a model of a large open economy, indicate that expansionary open market operations by the Federal Reserve at two critical junctures (October 1930 to February 1931; September 1931 through January 1932) would have been successful in averting the banking panics that occurred, without endangering convertibility. Indeed had expansionary open market purchases been conducted in 1930, the contraction would not have led to the international crises that followed.

Michael D. Bordo

Dept. of Economics

Rutgers University

New Brunswick, NJ 08901-1284

bordo@fas-econ.rutgers.edu

and NBER

Anna Schwartz

NBER

50 East 42nd St., 17th Floor

New York, NY 10017-5405

aschwar1@email.gc.cuny.edu
Ehsan U. Choudhri

Dept. of Economics

Carleton University

1125 Colonel by Drive

Ottawa, ON K1S 5B6

Canada

ehsan_choudhri@carleton.ca 


\section{Introduction}

A much-debated hypothesis about the Great Depression is Friedman and Schwartz's (1963) contention that a severe but not unusual US recession turned into the greatest contraction of all times because the Federal Reserve failed to undertake expansionary open-market operations. They would have offset a drastic decline in the stock of money attributable to a series of banking panics. Controversy about the role of monetary factors in causing the Great Depression in the US was a feature of the earlier literature, but the consensus of the recent literature is that monetary shocks (produced largely by a series of banking crises) played a major role in prolonging and deepening the Great Depression. ${ }^{1}$

International aspects of the Great Depression have also been the focus of attention in recent studies. Research on international experience shows conclusively that the countries that left the gold standard early suffered a less severe Depression than those that stayed on. ${ }^{2}$ The international transmission of the Great Depression occurred for two key reasons. First, fixed exchange rates under the gold standard transmitted adverse shocks from one country to another. Second, commitment to the gold standard deterred countries from pursuing expansionary monetary policies to counteract these shocks. ${ }^{3}$ The foregoing view of the gold standard is supportive of the Friedman-Schwartz hypothesis in so far as it helps explain how banking panics in the US could have produced a world-wide depression. However, this view also suggests that

\footnotetext{
${ }^{1}$ For a recent review of the causes of the US Depression, see Romer (1993).

${ }^{2}$ See, for example, Choudhri and Kochin (1980), Eichengreen and Sachs (1985), Bernanke and James (1991) and Bernanke (1995).

${ }^{3}$ Eichengreen (1992) documents the case of the central European countries (Austria, Germany, and Hungary), each of which in the summer of 1931 suffered banking crises. When the monetary authorities attempted to use expansionary policy to allay the banking crises, their currencies were subjected to speculative attacks, forcing them to abandon unrestricted convertibility to gold. Belgium in 1935 was forced off the gold standard under similar circumstances.
} 
gold standard constraints might have prevented the Federal Reserve from increasing highpowered money sufficiently to offset decreases in the money stock induced by banking crises. A policy of expanding domestic credit to stabilize the stock of money might have aroused doubts about US commitment to the gold standard and led to a loss of gold reserves. Eichengreen (1992) argues that the loss would have been sufficiently large to force the US off the gold standard.

His argument points to the imperatives of the international gold standard rather than ineptness of the Federal Reserve as primarily responsible for not averting the Great Depression. For Friedman and Schwartz (1963), however, the Federal Reserve held so large a stock of gold that even had such a loss occurred, it did not pose a serious threat to the US commitment to the gold standard.

Although there is considerable interest in this issue, little empirical work exists on estimating the loss of gold reserves that might have resulted, had the Federal Reserve undertaken expansionary monetary policy to offset the banking panics during the Great Depression. The main purpose of this paper is to undertake such an exercise.

Section 2 of the paper briefly reviews the history of the interwar gold standard, discusses key developments before and during the Great Depression, and focuses on the international crises from 1931 to 1933 . Section 3 then goes on to develop a model that identifies key determinants of gold flows from the US. The model can be used to simulate the behavior of gold reserves were monetary policy expansionary during banking panics. In view of the large size of the US economy, the model explicitly takes into account the interaction between the US and the rest of the world. Even in the special case of perfect capital mobility (which represents the most severe constraint for US policy), the model shows that the expansion of US domestic credit would have been only partially offset by gold flows and it would have been technically possible for the Federal Reserve to counter a decline in the stock of money. 
Section 4 empirically implements the paper's model using monthly data for four major countries, France, Germany, the UK and the US. We consider two hypothetical scenarios of expansionary monetary policy, one initiated after the first banking panic in October 1930, the second after the crisis associated with sterling's devaluation in September 1931. We account for possible speculative attacks suggested by the recent literature on first and second generation speculative attack models. We simulate the time path of US gold reserves (as well as that of the gold-reserve ratio) under the two hypothetical scenarios up to February 1933.

In the first simulation, we show that a $\$ 1$ billion open market purchase over the period October 1930-February 1931 could have prevented the banking panics that followed by providing the banking system with additional reserves, and would not have led to a gold drain in 1931-33 sufficient to deplete US gold reserves.

In the second simulation, we assume that the Federal Reserve would have increased domestic credit by $\$ 1$ billion after the British devaluation from September 1931 through January 1932. This policy would have been undertaken although the first hypothetical open market purchase would not have been. Subsequent to the open market purchase, we show that US gold reserves would have declined significantly but not sufficiently to reduce the gold ratio below the statutory minimum requirement. The reason for the hypothetical large gold outflows in this simulation, unlike the previous one, is that the British devaluation possibly could have shaken the market's confidence in the US commitment to gold parity. France would have conducted its policy of dollar conversion, as it would not have under simulation 1. Except for France, the rest of the world held limited dollar claims. 


\section{$\underline{\text { 2. Historical Background: Financial Crises of the Gold Exchange Standard }}$}

\subsection{Overview}

The gold standard dissolved during World War I as all major countries, with the exception of the United States, suspended gold convertibility de facto if not de jure. The gold exchange standard was restored worldwide in the period 1924-27, when central bank statutes typically required a cover ratio for currencies between 30 and 40 percent, divided between gold and foreign exchange. Central reserve countries (the US and UK) were to hold reserves only in the form of gold. By the end of 1928, 35 countries had their currencies officially convertible into gold.

The restoration of convertibility to sterling in 1925 at an overvalued parity and to the franc in 1928 at an undervalued parity led to maldistribution of gold, which was greatly aggravated by the inappropriate policies that France and the United States pursued. Each of them as well as other countries (Nurkse 1994) ${ }^{4}$ consistently sterilized gold inflows, which reduced gold reserves available to the rest of the world and enhanced deflationary pressure.

At the same time that France was absorbing gold from the rest of the world, so was the United States, the world's largest gold holder (see Figure 1). The Federal Reserve systematically sterilized gold inflows during the 1920s and 1930s (Friedman and Schwartz 1963). In June 1928, the US share of the world total monetary gold stock was 38.3 percent, the French share, 11.7 percent. In June 1931, the shares were, respectively, 40.8 and 19.6 percent (see Figure 2).

The gold exchange standard collapsed in the face of the shocks of the Great Depression.

\footnotetext{
${ }^{4}$ For example, the German Reichsbank, which adopted policies to accumulate gold and rebuild its reserve position following the German hyperinflation.
} 
Tight monetary policy by the Federal Reserve in 1928 to deflate the stock market boom and France's pro-gold policies precipitated a downturn in the US and the rest of the world in 1929. A series of banking panics in the US subsequently transmitted deflationary and contractionary pressures to the rest of the world on the gold standard.

As soon as doubts began to surface about the stability of the reserve currencies, central banks scrambled to liquidate their foreign exchange reserves and replace them with gold. The share of foreign exchange in global central bank reserves plummeted from 37 percent at the end of 1930 to 13 percent at the end of 1931 and 11 percent at the end of 1932 (Nurkse 1944, App. II). The implosion of the foreign-exchange component of the global reserve base exerted strong deflationary pressure on the world economy. Although total world gold reserves increased by $\$ 1$ billion between 1930 and 1932 -- deflation stimulated gold output -- it was not enough to satisfy the heightened central bank demand. To attract gold, they jacked up interest rates in the face of an unprecedented slump.

\subsection{Chronology of the Breakdown of the Gold Exchange Standard}

Against the background of the international gold exchange standard, we consider in more detail the events of 1931-33, when US adherence to gold may have been threatened. We focus on three episodes: Fall 1931, Spring 1932, and Spring 1933, when the US may have faced speculative attacks on the dollar. We then discuss the available evidence on speculation at these three dates.

\subsubsection{The UK Suspends Gold Convertibility, Autumn 1931}

Early strains on the gold exchange standard appeared in 1927. An incipient run on sterling in July 1927 , following massive capital flows to France, was averted by the cooperative action by the central banks of the four core countries. As its contribution to the cooperative arrangement, the Federal Reserve reduced the discount rate and the buying rate on bankers' acceptances. 
Although the 1929 downturn produced strain on sterling, the defining crisis of the gold exchange system occurred in 1931. The failure of the Austrian Creditanstalt in May 1931 led to a German crisis with internal drains from the banking system. Only later were foreign deposits withdrawn. The Bank of England extended short-term credits to the crisis-stricken central European countries, whose reserves had been declining in the face of persistent balance of payments deficits. A speculative attack in September 1931 on the Bank was successful (Capie, Mills, and Wood 1986). Johnson (1997) notes that Britain gave up, not because of an immediate crisis -- it floated after raising the discount rate to only $4 \frac{1}{12}$ percent -- but because of the longterm problem in its balance of payments, with no foreseeable improvement. ${ }^{5}$

French pressure then forced the Federal Reserve to raise the US discount rate in two steps within a week by an unprecedented 2 percentage points from $1 \frac{1}{2}$ to $3 \frac{1}{2}$ percent as a quid pro quo for delaying conversion into gold of more than $\$ 500$ million the French held in dollar assets. This action halted the external drain but only served to exacerbate a domestic banking panic.

\subsubsection{Federal Reserve Open Market Operations, Spring 1932}

From March through June 1932, under Congressional pressure, the Federal Reserve pursued an expansionary open market policy, purchasing $\$ 1$ billion in government securities. According to Friedman and Schwartz, the policy was successful in halting the downturn. It was ended, however, although much too soon, once Congress went into recess. Federal Reserve officials, who adhered to a deflationary real bills doctrine, did not believe that further purchases would help the banks or improve the economy. Eichengreen, however, contends that the Federal Reserve stopped the purchase program because of concern over its gold reserves, especially the

\footnotetext{
${ }^{5}$ According to Eichengreen and Jeanne (1998), the British devalued sterling because of rising unemployment, which made it impossible to pursue the contractionary policies required to defend the parity.
} 
level of free gold. Although gold reserves declined through June 1932, at $\$ 3.5$ billion they were still above the statutory limit. July 1932 marked the end of central bank withdrawals from New York.

\subsubsection{The US Bank Holiday, March 1933}

The final crisis of the dollar occurred in 1933. Massive banking panics across the US led to a series of state bank holidays.

Fears that the newly elected President Roosevelt would devalue the dollar upon taking office led mainly domestic residents to convert dollars into gold. Speculators in New York for the first time bought sterling.

The decline in the gold reserves of the Federal Reserve Bank of New York below its statutory limit triggered the request for New York State to grant a Bank Holiday on Friday, March 3, and Roosevelt's decision to declare a one-week national Bank Holiday on Monday, March 6. The Bank Holiday succeeded in allaying the banking panic and in halting the gold drain. Although the link with gold was cut in the following month, a modest gold drain did not resume until some months before the Gold Reserve Act was passed on January 31, 1934.

\subsubsection{Evidence on Speculative Activity Against the Dollar}

To examine in greater detail the view that expansionary monetary policy would have aroused speculative activity against the dollar, we look at the available sources of information on the subject. ${ }^{6}$

\footnotetext{
${ }^{6}$ There are two main sources of statistical information about the willingness of foreigners to hold dollar exchange. One source is a table showing outstanding amounts of short-term foreign liabilities reported by banks in New York City, including the Federal Reserve Bank of New York, at end-of-month dates beginning May 1929 through June 1931, thereafter weekly (Banking and Monetary Statistics 1943, Table 161). Detail is available through mid-February 1932 for 6, subsequently 9 European countries, the rest, and total Europe, and 4 other areas. The second source is a monthly table from 1914 on, showing the U.S. monetary gold stock, net gold imports, and gold under earmark (ibid., Table 156). In addition, weekly Saturday quotations of spot and forward rates for one month and three months of the dollar and six other European currencies are available (Einzig 1937). The forward rates show the premium or discount in relation to sterling.
} 
The question about possible speculative activity centers on the Fall of 1931 and the Spring of 1932. That speculation arose in the weeks before the Roosevelt administration took office in March 1933 is unquestionable. The trigger, however, was not expansionary monetary policy, but rumors that the gold content of the dollar would be devalued, which turned out to be true.

At the earlier dates, suppose the data show a loss of gold by the US. Is this evidence that the dollar was under attack? Suppose the data show an acceleration of a loss of gold. Is this evidence of a heightened attack on the dollar? The problem of interpretation arises because the official holders of dollar claims in the continental creditor countries had a motive other than doubts about the US to want to increase their gold reserves. The motive to convert all dollar exchange into gold may well have been paramount -- whatever the condition of the US.

Moreover, gold withdrawals from the US were arranged with the consent of the US. It was not necessarily the case that an increase in withdrawals spelled increased lack of confidence in the US.

What do we learn from the sources at the two dates when the United States may have faced attacks on the dollar?

In the first of the three episodes, in the six weeks following British suspension of the gold standard in September 1931, short-term liabilities of U.S. banks to Europeans declined by $\$ 400$ million, the U.S. monetary gold stock declined by $\$ 450$ million, and the combined monetary gold stock of France, Belgium, Netherlands, and Switzerland rose by an equivalent amount.

As Brown (1940, 1222) states, the gold drain has been described "incorrectly, as attacks upon the dollar." While the U.S. lost gold to the European gold standard countries, in September

\footnotetext{
The sources do not distinguish private from official holders of dollar exchange nor when the US lost gold how much was transferred to private or official claimants. Under the gold exchange standard, official holders of dollar exchange were clearly significant participants in the foreign exchange market and data on their gold holdings can be correlated with opposite movements in U.S. gold.
} 
and October 1931, it still drew gold from Argentina, Canada, and Japan. The main drain was to France. France had an "uncompromising hostility to the gold exchange standard" (Brown 1940, p. 1179), but it did not seek "wholesale conversion" of its dollar balances either before or after September 21, the date of British suspension. This was not a speculative attack, in the sense of the current use of those terms. According to Einzig (1937, p. 269) the forward dollar rate depreciated for two weeks from October 17 to 31 , and then went to a premium for the rest of the year. This was a transitory dollar scare, at best, not a settled loss of confidence in the dollar.

Two emissaries of the Bank of France arrived in America in October to discuss with the Federal Reserve and the Treasury the terms under which its dollar balances would be withdrawn. At the end of the month a communiqué by Hoover and Laval on a visit to Washington emphasized the maintenance of the gold standard in France and the United States as essential for the restoration of economic stability and confidence. Randolph Burgess at the October meeting of the board of the BIS gave official assurance that the American gold standard was not in danger. In November and December 1931 the foreign drain temporarily ceased.

The second episode when the U.S. may have faced a speculative attack was during the Federal Reserve open market purchase from March to June 1932. During this period short-term liabilities of U.S. banks to Europeans declined by $\$ 550$ million, the U.S. monetary gold stock declined by $\$ 535$ million, and the combined increase in the European gold standard countries' gold was \$280 million. The liquidation of dollar balances by France, Holland, Belgium, and Switzerland, which was completed by July 1932, was arranged to minimize disturbances to the American market. Was this a speculative attack, when the so-called attackers sought to achieve their objective with the least possible damage to the victim? During the period of gold loss to the continental creditor countries, and during the second half of 1932, Canada, South America, and the Far East continued to ship gold to the US -- a measure of confidence in the US commitment 
to the gold standard.

By the end of 1932, the US gold stock was at a level higher than in October 1931. According to Henry Parker Willis (1934, p. 17), there was no threat to the gold standard even at the height of the continental withdrawals: "fears of a European drain, general among reserve bankers" in 1932, "had proven mythical."

Einzig (1937, p. 270) describes the forward dollar in the first half of 1932 as "abnormally undervalued, compared to its interest parities." This was the period when the Federal Reserve was actually conducting open market purchases that clearly did not drive the U.S. off gold even if the evidence in the forward rate is regarded as a possible speculative attack on the dollar. The attack failed and post-June 1932, the forward rate was brought practically to parity with spot dollars.

Although there is little evidence that speculation against the dollar in the modern sense of the recent speculative attack literature was forthcoming from official sources, it is still possible that private agents in other countries or in the US, acting alone or through investment banks and other intermediaries could have taken a speculative position against the dollar in 1931 and 1932. The available data does not permit us to isolate these actions. Furthermore we were unable to find any mention of such activities in the narratives of knowledgeable contemporaries to which we had access.

The third episode of gold loss in February 1933, as indicated above, was unlike the earlier ones. Withdrawals by foreign countries had greatly reduced their US balances. They were no longer a threat to dollar, if they ever were. Foreigners had essentially completed their withdrawals by the beginning of August 1932, and had built up dollar holdings during the next half year.

The British Exchange Equalisation Account (which held dollars valued at 46 million pounds, at the current exchange rate of $\$ 3.36$ per pound) in January 1933 began to replace dollars 
with gold. It did so partly at the request of the Federal Reserve Bank of New York, which was afraid of sudden gold withdrawals, and partly because of the possibility of an American devaluation (Howson 1980, p. 35). The British withdrew only 8 million pounds equivalent in dollars during the next two months. During the four weeks from the beginning of February until the Bank Holiday, withdrawals amounted only to $\$ 150$ million. Remaining balances were held to service ordinary transactions.

This time it was the US banking crisis that began during the 1932 Presidential campaign that was one cause for concern. Another was that after Roosevelt's victory there was ground for the belief that the U.S. would leave the gold standard. Private investors and private bankers sold dollars short and used the proceeds to buy sterling. In addition, depositors who withdrew funds previously held as currency now demanded gold for dollars. Willis believed that it should have been possible "to offset and cancel the effects of such transactions and demands" (p. 19), given central bank tools, the size of the US monetary gold stock, a favorable trade balance, and sizable foreign investments. Instead, he describes Federal Reserve managers as thrown "into a condition bordering on panic" (1934, p. 14). They were ready to surrender the gold standard, when there was no fundamental reason to do so.

\subsection{Could Expansionary Monetary Policy Have Averted the Crises of the Gold Exchange}

\section{$\underline{\text { Standard? }}$}

Eichengreen (1992) argues that under the gold standard banking crises and currency crises were intertwined. In the Depression experiences of a number of European countries, incipient banking crises were aggravated by capital flight, as both domestic and foreign deposits were shifted abroad in anticipation of capital controls and devaluation. Central banks refrained from acting as lenders of last resort to provide liquidity to their banking systems because of fear that expansionary domestic credit would precipitate an attack on their gold reserves. The only solution 
to the dilemma was to cut the link with gold and devalue. ${ }^{7}$

This analysis, which seems sound for the experience of the small open economies of Europe, may not apply to the US case, a large, relatively closed economy, with very substantial gold reserves. The issue is, how much gold would have been lost had the US followed the requisite expansionary open market purchases to counter the banking panics, and would the gold losses have been sufficient to breach the required gold cover statute of 40 percent against Federal Reserve notes and 35 percent against Federal Reserve deposits.

An auxiliary issue relates to free gold, the excess of gold reserves over that required to meet the statutory 40 percent reserve requirement against notes and to cover the shortfall of eligible securities backing the remaining 60 percent of Federal Reserve notes. According to Eichengreen (1992), by the end of 1931 Federal Reserve free gold had fallen below what he regards as the critical level of $\$ 500$ million. This level of free gold, he maintains, would not have allowed the Federal Reserve to conduct an open market purchase sufficient to make up the $\$ 2$ billion decline in M1 that had occurred after the UK left gold. At a later point, we note that Eichengreen's conjecture is erroneous, since he neglects the role of the money multiplier that, together with the change in high-powered money, determines the change in M1.

For two reasons we also are skeptical that the level of free gold was an actual constraint

\footnotetext{
${ }^{7}$ In his conclusion Eichengreen $(1992,392-93)$ states: “. . . the failure of monetary . . . authorities to take offsetting action once the Depression was underway is no longer perplexing once one acknowledges the role of gold standard constraints. Unilateral action to ... make available additional money and credit was certain to create balance of payments deficits where they did not already exist and to magnify these deficits with which central banks were already attempting to cope.... gold convertibility would be threatened. Even the provision of liquidity to a banking system in distress might cast doubt over the official commitment to gold, prompting the transfer of bank deposits out of the country and aggravating the problem of domestic financial instability. The Federal Reserve and the Bank of France, possessing extensive gold reserves, were less immediately threatened than other central banks. But even they had very limited room for maneuver (our emphasis)." And earlier he comments (p. 295): "In principle, the Fed could have used expansionary open market operations to prevent the decline in the money supply. It refused to do so for fear of endangering the gold parity," although he does not cite any supporting statement by a Fed official.
} 
on Federal Reserve monetary policy. It never reported dollar amounts of free gold. Only in its 1932 annual report (p. 17), issued four months after the Glass-Steagall Act was passed, did it present a chart for 1929-32, based on last-Wednesday of the month total gold reserves, with different shading for required reserves, additional gold needed as collateral, and free gold. Eichengreen, in his eyeball reading from the chart, states that free gold in October 1931 was reduced to $\$ 400$ million. If it were in fact at that low level that month, it is all the more incomprehensible that the Federal Reserve did not move heaven and earth to force a change in eligibility requirements. The impression that free gold was not in fact the deterrent to expansionary monetary policy that the Federal Reserve and its supporters allege it to have been is further bolstered by Hoover's complaint $(1952,115-18)$ that, although he had proposed on October 6,1931, that eligibility requirements be broadened, no action had been taken until four months later. At a meeting at the White House with Governor Harrison of the New York Fed and Governor Meyer of the Board on February 8, 1932, the situation was said to be critical, and Hoover's proposal was finally agreed to. In addition, there is no evidence that the Federal Reserve during the months between the British abandonment of gold and the adoption of the GlassSteagall Act was lobbying for this crucial legislative change. The failure of Congress to act on Hoover's proposal suggests the absence of any urgency. We therefore question whether free gold was truly a constraint on Federal Reserve performance.

The Federal Reserve acknowledged in the report that although free gold amounted to only $\$ 416$ million on February 24, 1932, when the act was adopted, it could have been increased to $\$ 542$ million simply by reducing the volume of Federal Reserve notes held by Federal Reserve banks in their own vaults. At no point did the Federal Reserve take such a step to increase free gold. Moreover, although the Federal Reserve held $\$ 740$ million in U.S. government securities, they were not pledged as collateral backing for Federal Reserve notes until May 5, 1932 (p. 19), 
months after it had the authority to do so. The story that free gold was the reason it could not conduct open market purchases should be swallowed with a big dose of salt. The statements by Secretary Ogden Mills and Randolph Burgess in the weeks before enactment of Glass-Steagall that Eichengreen cites about how close the U.S. was to being forced off the gold standard should be understood as political strong-arming to get the bill passed. Incidentally, as we noted at an earlier point, Randolph Burgess assured the BIS that the gold standard was not in danger in October 1931, despite Eichengreen's low-ball figure for free gold that month. ${ }^{8}$

A second issue of importance is that the effect of Federal Reserve expansionary policies would have been sufficient to prevent banking panics in the US from having effects on the rest of the world. Such policies would have prevented crises elsewhere. Had the US money supply not collapsed, deflationary pressure on the rest of the world might have been avoided.

\section{Basic Model}

This section develops a basic two-country model to determine US gold flows and to provide a framework for simulating the behavior of US gold reserves under alternative monetary policies. We assume that the US demand for money in period $t$ is given by

$$
\text { (1) } \mathrm{m}_{\mathrm{t}}-\mathrm{p}_{\mathrm{t}}=\alpha_{0}+\alpha_{1} \mathrm{y}_{\mathrm{t}}+\alpha_{2} \mathrm{i}_{\mathrm{t}}+\mathrm{v}_{\mathrm{t}}, \alpha_{1}>0, \alpha_{2}<0 \text {, }
$$

where $\mathrm{m}_{\mathrm{t}}, \mathrm{p}_{\mathrm{t}}$ and $\mathrm{y}_{\mathrm{t}}$ represent logs of the money stock, the price level and real income, $\mathrm{i}_{\mathrm{t}}$ denotes the interest rate and $v_{t}$ is the error term. The determinants of $m_{t}$ can be expressed by the following two identities:

$$
\text { (2) } \mathrm{m}_{\mathrm{t}} \equiv \mu_{\mathrm{t}}+\log \left(\mathrm{H}_{\mathrm{t}}\right) \text {, }
$$

\footnotetext{
${ }^{8}$ Meltzer also argues that, if free gold was in fact a binding constraint, the Federal Reserve could have followed earlier precedent and temporarily suspended gold reserve requirements.
} 


$$
\text { (3) } H_{t}=G_{t}+D_{t} \text {, }
$$

where $\mu_{t}$ is the log of the money multiplier while $H_{t}, G_{t}$ and $D_{t}$ represent high-powered money, gold reserves and domestic credit (defined as high-powered money excluding gold reserves).

Using (1) - (3) after expressing these relations in first differences, and utilizing the approximation that $\Delta \log \left(\mathrm{H}_{\mathrm{t}}\right)=\Delta \mathrm{H}_{\mathrm{t}} / \overline{\mathrm{H}}_{\mathrm{t}}$ with $\overline{\mathrm{H}}_{\mathrm{t}} \equiv\left(\mathrm{H}_{\mathrm{t}}+\mathrm{H}_{\mathrm{t}-1}\right) / 2$, we derive the following relation for determining US gold flows:

$$
\Delta \mathrm{G}_{\mathrm{t}} / \overline{\mathrm{H}}_{\mathrm{t}}=-\Delta \mathrm{D}_{\mathrm{t}} / \overline{\mathrm{H}}_{\mathrm{t}}-\Delta \mu_{\mathrm{t}}+\Delta \mathrm{p}_{\mathrm{t}}+\alpha_{1} \Delta \mathrm{y}_{\mathrm{t}}+\alpha_{2} \Delta \mathrm{i}_{\mathrm{t}}+\Delta \mathrm{V}_{\mathrm{t}}
$$

Equation (4) can be utilized to examine the effect of an expansion in domestic credit on gold flows. Although the direct effect of $\Delta \mathrm{D}_{\mathrm{t}}$ on $\Delta \mathrm{G}_{\mathrm{t}}$ equals -1 in (4), $\Delta \mathrm{D}_{\mathrm{t}}$ could also exert an indirect effect through other variables on the right hand side of (4). Over a very short period (say, a month), it is plausible to assume that $\Delta \mu_{\mathrm{t}}, \Delta \mathrm{p}_{\mathrm{t}}, \Delta \mathrm{y}_{\mathrm{t}}$ and $\Delta \mathrm{V}_{\mathrm{t}}$ are exogenous to $\Delta \mathrm{D}_{\mathrm{t}}$ and $\Delta \mathrm{i}_{\mathrm{t}}$ is the only potential channel for the indirect effect. We explicitly model the monetary relations in the rest of the world to explore this channel.

Assuming that the money demand function in the rest of the world is of the same form as (1), representing the determinants of money stocks by identities similar to (2) and (3), and using an asterisk to denote rest-of-the-world variables and parameters, we obtain

$$
\Delta \mathrm{G}_{\mathrm{t}}^{*} / \overline{\mathrm{H}}_{\mathrm{t}}^{*}=-\Delta \mathrm{D}_{\mathrm{t}}^{*} / \overline{\mathrm{H}}_{\mathrm{t}}^{*}-\Delta \mu_{\mathrm{t}}^{*}+\Delta \mathrm{p}_{\mathrm{t}}^{*}+\alpha_{1}^{*} \Delta \mathrm{y}_{\mathrm{t}}^{*}+\alpha_{2}^{*} \Delta_{\mathrm{i}_{\mathrm{t}}}^{*}+\Delta \mathrm{v}_{\mathrm{t}}^{*},
$$

where nominal variables, $\mathrm{G}_{\mathrm{t}}^{*}, \mathrm{D}_{\mathrm{t}}^{*}$ and $\overline{\mathrm{H}}_{\mathrm{t}}^{*}\left[\equiv\left(\mathrm{H}_{\mathrm{t}}^{*}+\mathrm{H}_{\mathrm{t}-1}^{*}\right) / 2\right]$, are expressed in foreign-currency units. ${ }^{9}$ Assume that the world stock of gold is fixed and the US price of gold is constant over time. These assumptions imply that gold flows in the US and the rest of the world are linked as follows:

\footnotetext{
${ }^{9}$ In this relation non-gold international reserves are included in $\mathrm{D}^{*}$.
} 


$$
\text { (6) } \Delta \mathrm{G}_{\mathrm{t}}=-\Delta\left(\mathrm{e}_{\mathrm{t}} \mathrm{G}_{\mathrm{t}}^{*}\right)
$$

where $e_{t}$ denotes the exchange rate in representing the price of foreign currency in US dollars.

We express the relationship between interest rates in the US and abroad as

$$
\text { (7) } \quad i_{t}=i_{t}^{*}+x_{t}+\varepsilon_{t}
$$

where $\mathrm{X}_{\mathrm{t}}$ denotes the expected rate of US dollar depreciation and $\varepsilon_{\mathrm{t}}$ represents departures from perfect capital mobility (or uncovered interest parity) caused by factors such as risk premia, transaction costs, information lags and capital controls. If the gold standard had operated smoothly, no changes in gold parities would have been expected and $\mathrm{x}_{\mathrm{t}}$ would have equalled zero. In this case, the Federal Reserve would still have been able to affect the interest rate differential, $i_{t}-i_{t}^{*}$, if departures from perfect capital mobility allowed it to systematically influence $\varepsilon_{\mathrm{t}}$. However, even if the interest rate differential could not have been changed by the Federal Reserve, the large size of the US would have permitted it to affect the world interest rate and hence follow an independent monetary policy under the gold standard.

Using (4), (5), (6) and the first-difference form of (7), we derive the following relation that explicitly shows the key US and rest-of-the-world variables which determine US gold flows:

(8) $\Delta \mathrm{G}_{\mathrm{t}} / \overline{\mathrm{H}}_{\mathrm{t}}=\theta_{\mathrm{t}}\left[-\Delta \mathrm{D}_{\mathrm{t}} / \overline{\mathrm{H}}_{\mathrm{t}}-\Delta \mu_{\mathrm{t}}+\Delta \mathrm{p}_{\mathrm{t}}+\alpha_{1} \Delta \mathrm{y}_{\mathrm{t}}+\alpha_{2}\left(\Delta_{\mathrm{X}_{\mathrm{t}}}+\Delta \varepsilon_{\mathrm{t}}\right)+\Delta \mathrm{V}_{\mathrm{t}}\right]$

$$
+\left(\theta_{\mathrm{t}} \alpha_{2} / \alpha_{2}^{*}\right)\left(\Delta \mathrm{D}_{\mathrm{t}}^{*} / \overline{\mathrm{H}}_{\mathrm{t}}^{*}+\Delta \mu_{\mathrm{t}}^{*}-\Delta \mathrm{p}_{\mathrm{t}}^{*}-\alpha_{1}^{*} \Delta \mathrm{y}_{\mathrm{t}}^{*}-\Delta_{\mathrm{V}_{\mathrm{t}}}^{*}+\gamma_{\mathrm{t}}\right)
$$

where $\theta_{\mathrm{t}} \equiv \alpha_{2}^{*} \mathrm{e}_{\mathrm{t}} \overline{\mathrm{H}}_{\mathrm{t}} /\left(\alpha_{2} \overline{\mathrm{H}}_{\mathrm{t}}+\alpha_{2}^{*} \mathrm{e}_{\mathrm{t}} \overline{\mathrm{H}}_{\mathrm{t}}^{*}\right)$ and $\gamma_{\mathrm{t}} \equiv-\Delta \mathrm{e}_{\mathrm{t}} \mathrm{G}_{\mathrm{t}-1}^{*} / \mathrm{e}_{\mathrm{t}} \overline{\mathrm{H}}_{\mathrm{t}}^{*}$. Note that the term, $\gamma_{\mathrm{t}}$, represents an adjustment for changes in the foreign price of gold and in periods when this price is constant, it equals zero. Although, for simplicity, we have discussed the derivation of (8) in terms of one foreign country, this equation, in fact, generalizes to any number of foreign countries under the assumption that all foreign countries have the same money demand functions. In this multi- 
country case, rest-of-the-world variables represent weighted averages of country variables with each country's weight equal to its share of the rest-of-the-world stock of high-powered money. ${ }^{10}$

We can use (8) to examine the offset coefficient - - that is, the proportion of an increase in US domestic credit offset by gold outflows in the short run. Consider the special case in which: (1) no changes in gold parities are expected and thus $x_{t}$ equals zero, and (2) there is either perfect capital mobility so that $\varepsilon_{\mathrm{t}}$ equals zero or near-perfect capital mobility in the sense that $\Delta \varepsilon_{\mathrm{t}}$ is independent of $\Delta \mathrm{D}_{\mathrm{t}}$. In this case, (8) implies that the offset coefficient equals $-\theta_{\mathrm{t}}$. As the US stock of high-powered money represented a substantial portion of the world stock during the Great Depression, $\theta_{\mathrm{t}}$ was significantly less than one. Thus even with perfect or near-perfect capital mobility, gold flows would not have severely constrained the Federal Reserve's ability to determine the high-powered stock of money in the short run. The Federal Reserve would, of course, have been less constrained under imperfect mobility in which case the absolute value of the offset coefficient would be smaller than $\theta_{\mathrm{t}}{ }^{11}$

${ }^{10}$ Basic relations for country $\mathrm{j}$ in the rest of the world are $\Delta \mathrm{G}_{\mathrm{t}}^{\mathrm{j}} / \overline{\mathrm{H}}_{\mathrm{t}}^{\mathrm{j}}=-\Delta \mathrm{D}_{\mathrm{t}}^{\mathrm{j}} / \overline{\mathrm{H}}_{\mathrm{t}}^{\mathrm{j}}-\Delta \mu_{\mathrm{t}}^{\mathrm{j}}+\Delta \mathrm{p}_{\mathrm{t}}^{\mathrm{j}}+\alpha_{1}^{*} \Delta \mathrm{y}_{\mathrm{t}}^{\mathrm{j}}+\alpha_{2}^{*} \Delta_{\mathrm{i}}^{\mathrm{j}}+\Delta \mathrm{v}_{\mathrm{t}}^{\mathrm{j}}$, and $\Delta_{\mathrm{i}_{\mathrm{t}}}=\Delta \mathrm{i}_{\mathrm{t}}^{\mathrm{j}}+\Delta \mathrm{X}_{\mathrm{t}}^{\mathrm{j}}+\Delta \varepsilon_{\mathrm{t}}^{\mathrm{j}}$, where the superscript denotes the country's variables. Letting $e_{t}^{j}$ denote the exchange rate in terms of a reference currency, define $\mathrm{w}_{\mathrm{t}}^{\mathrm{j}} \equiv \mathrm{e}_{\mathrm{t}}^{\mathrm{j}} \overline{\mathrm{H}}_{\mathrm{t}}^{\mathrm{j}} / \overline{\mathrm{H}}_{\mathrm{t}}^{*}$ with $\bar{H}_{t}^{*} \equiv \sum_{j} e_{t}^{j} \bar{H}_{t}^{j}$. Multiplying both sides of the above relations by $\mathrm{w}_{\mathrm{t}}^{\mathrm{j}}$ and aggregating over all countries in the rest of the world, we obtain (5) and the first difference form of (7) with $\xi_{\mathrm{t}}^{*}=\sum_{\mathrm{j}} \mathrm{W}_{\mathrm{t}}^{\mathrm{j}} \xi_{\mathrm{t}}^{\mathrm{j}}$ for $\xi=\Delta \mu, \Delta \mathrm{p}, \Delta \mathrm{y}, \Delta \mathrm{i}, \Delta \mathrm{v} ; \Delta \mathrm{G}_{\mathrm{t}}^{*} / \overline{\mathrm{H}}_{\mathrm{t}}^{*}=\sum_{\mathrm{j}} \mathrm{w}_{\mathrm{t}}^{\mathrm{j}} \Delta \mathrm{G}_{\mathrm{t}}^{\mathrm{j}} / \overline{\mathrm{H}}_{\mathrm{t}}^{\mathrm{j}} ; \Delta \mathrm{D}_{\mathrm{t}}^{*} / \overline{\mathrm{H}}_{\mathrm{t}}^{*}=\sum_{\mathrm{j}} \mathrm{w}_{\mathrm{t}}^{\mathrm{j}} \Delta \mathrm{D}_{\mathrm{t}}^{\mathrm{j}} / \overline{\mathrm{H}}_{\mathrm{t}}^{\mathrm{j}} ; \Delta \mathrm{X}_{\mathrm{t}}=\sum_{\mathrm{j}} \mathrm{w}_{\mathrm{t}}^{\mathrm{j}} \Delta \mathrm{X}_{\mathrm{t}}^{\mathrm{j}} ;$ and $\Delta \varepsilon_{\mathrm{t}}=\sum_{\mathrm{j}} \mathrm{W}_{\mathrm{t}}^{\mathrm{j}} \Delta \varepsilon_{\mathrm{t}}^{\mathrm{j}}$. Relation (6) changes to $\Delta \mathrm{G}_{\mathrm{t}}=-\mathrm{e} \sum_{\mathrm{j}} \Delta\left(\mathrm{e}_{\mathrm{t}}^{\mathrm{j}} \mathrm{G}_{\mathrm{t}}^{\mathrm{j}}\right)$, where $\mathrm{e}$ is the price of the reference currency in US dollars (assumed, for simplicity, to be constant over time). Then using revised (6) along with (4), (5) and the first difference form of (7), we obtain (8) with $\gamma_{t}=-\sum_{j} w_{t}^{j} \Delta e_{t}^{j} G_{t-1}^{j} / e_{t}^{j} \bar{H}_{t}^{j}$.

${ }^{11}$ Under imperfect capital mobility, an increase in domestic credit would lower the interest-rate differential via a decrease in $\varepsilon_{\mathrm{t}}$. If we assume, for simplicity, that $\varepsilon_{\mathrm{t}}=\pi \Delta \mathrm{D}_{\mathrm{t}} / \overline{\mathrm{H}}_{\mathrm{t}}+\varepsilon_{\mathrm{t}-1}$, with $\pi<0$, then the offset coefficient would equal $-\theta_{\mathrm{t}}\left(1-\pi \alpha_{2}\right)$ according to (8). 
To simplify the model, suppose that the income and semi-interest elasticities of the money demand function are the same in both the US and the rest of the world, and the income elasticity equals unity. For this case (assumed in the basic simulation discussed in the next section), setting $\alpha_{1}=\alpha_{1}^{*}=1$ and $\alpha_{2}=\alpha_{2}^{*}$, we can simplify (8) as

(9) $\Delta G_{t}=s_{t} \bar{H}_{t}\left[-\Delta D_{t} / \bar{H}_{t}+\Delta D_{t}^{*} / \bar{H}_{t}^{*}-\Delta \mu_{t}+\Delta \mu_{t}^{*}+\Delta p_{t}^{\prime}+\Delta y_{t}^{\prime}+\gamma_{t}+u_{t}\right]$,

where $s_{t}=e_{t} \bar{H}_{t}^{*} /\left(e_{t} \bar{H}_{t}^{*}+\bar{H}_{t}\right), \Delta p_{t}^{\prime} \equiv \Delta p_{t}-\Delta p_{t}^{*}, \Delta y_{t}^{\prime} \equiv \Delta y_{t}-\Delta y_{t}^{*}$ and $\mathrm{u}_{\mathrm{t}} \equiv \alpha_{2}\left(\Delta_{\mathrm{X}_{\mathrm{t}}}+\Delta \varepsilon_{\mathrm{t}}\right)+\Delta \mathrm{V}_{\mathrm{t}}-\Delta_{\mathrm{V}_{\mathrm{t}}}^{*}$

We use the above model to construct expansionary money counterfactuals, which would have allowed the Federal Reserve to pursue a monetary policy to prevent large decreases in the stock of money. Our counterfactuals distinguish policy needed during normal periods from policy needed during banking panics. During normal periods, small changes in domestic credit would suffice to produce money growth that is consistent with the gold standard. During banking panics, on the other hand, a key consideration would be to restore confidence in the banking system. An appropriate policy in these circumstances would be to expand domestic credit sufficiently to relieve shortages of bank reserves and avoid panic-induced bank failures. Expansionary monetary policy can thus be expressed as

$$
\Delta \mathrm{D}_{\mathrm{t}}=\left\{\begin{array}{l}
\delta_{\mathrm{t}}^{\mathrm{n}} \text { during normal periods } \\
\delta_{\mathrm{t}}^{\mathrm{b}} \text { during banking panics }
\end{array},\right.
$$

where $\delta_{\mathrm{t}}^{\mathrm{b}}$, determined by the lender-of-the-last-resort considerations, would tend to be large relative to $\delta_{\mathrm{t}}^{\mathrm{n}} \cdot{ }^{12}$ Note that expansionary actions are required only during banking panics. With

\footnotetext{
${ }^{12}$ To increase bank reserves, $\delta_{t}^{b}$ would have to be large enough to exceed $\Delta C_{t}-\Delta G_{t}$, where $C$ is the currency held by public. The amount needed to satisfy this condition would be especially large if a currency drain during a banking panic is accompanied by gold outflows caused by speculation.
} 
appropriate policy during normal periods (i. e., suitable choice of $\delta_{t}^{n}$ ), (10) would be compatible with fixed gold parities in the long run.

Given policy (10), US gold flows would be determined by (9) and the following two relations implied by (3), its rest-of the-world counterpart and (6) with $\mathrm{e}_{\mathrm{t}}=\mathrm{e}$ :

$$
\begin{aligned}
& \mathrm{H}_{\mathrm{t}}=\mathrm{H}_{\mathrm{t}-1}+\Delta \mathrm{D}_{\mathrm{t}}+\Delta \mathrm{G}_{\mathrm{t}}, \\
& \mathrm{H}_{\mathrm{t}}^{*}=\mathrm{H}_{\mathrm{t}-1}^{*}+\Delta \mathrm{D}_{\mathrm{t}}^{*}-\Delta \mathrm{G}_{\mathrm{t}} / \mathrm{e},
\end{aligned}
$$

To construct our counterfactuals, we do not explicitly model the determinants of gold flows, $\Delta \mathrm{D}_{\mathrm{t}}^{*}, \Delta \mu_{\mathrm{t}}, \Delta \mu_{\mathrm{t}}^{*}, \Delta p_{t}^{\prime}, \Delta y_{t}^{\prime}$ and $\mathrm{u}_{\mathrm{t}}$. However, we first make certain plausible assumptions (discussed below) about how expansionary monetary policy would affect their time paths. Given the assumed time paths, we solve the model represented by (9) and (10)-(12) for the time paths of $\Delta \mathrm{G}_{\mathrm{t}}, \Delta \mathrm{D}_{\mathrm{t}}, \mathrm{H}_{\mathrm{t}}$ and $\mathrm{H}_{\mathrm{t}}^{*}$. This solution is used to simulate the behavior of US gold reserves, $\mathrm{G}_{\mathrm{t}}$, and the ratio of gold reserves to high-powered money, $\mathrm{G}_{\mathrm{t}} / \mathrm{H}_{\mathrm{t}}$.

\section{Simulations of US Gold Reserves and the Gold-Reserve Ratio}

We now empirically implement our model using monthly data from 1926:7 to 1933:2, which period begins with all major countries adhering to the gold standard and ends with the US leaving the gold standard. To estimate the rest-of-the-world variables in our model, we use data for three large countries, the UK, France and Germany. ${ }^{13}$ These countries accounted for a significant proportion of high-powered money and the monetary gold stock held outside the US. ${ }^{14}$ However, the omission of other countries with significant gold reserves could bias our estimates

\footnotetext{
${ }^{13}$ For the data used, see the Data Appendix.

${ }^{14}$ The share of the UK, France and Germany in central bank gold reserves minus the US share in 1929-31 is 57 percent. The world consists of the 21 countries included in Bordo and Eichengreen (1998b), which account for about 75 percent of the 1928 total in Federal Reserve (1943). The same share for high-powered money for the three countries as a share
} 
and we explore the magnitude of this bias later. The price levels and outputs were measured by indexes of consumer (retail) prices and industrial production. As monthly series for these indexes were very noisy, they were smoothed using the Hodrick-Prescott filter.

Before discussing our expansionary-money counterfactuals, we briefly examine how our model fits monthly data on US gold flows. We can express relation (9) in the following testable form:

$$
\text { (13) } \Delta \mathrm{G}_{\mathrm{t}} / \mathrm{s}_{\mathrm{t}} \overline{\mathrm{H}}_{\mathrm{t}}=\beta_{0}+\beta_{1} \mathrm{z}_{\mathrm{t}}+\mathrm{u}_{\mathrm{t}}
$$

where $z_{t}=-\Delta D_{t} / \bar{H}_{t}+\Delta D_{t}^{*} / \bar{H}_{t}^{*}-\Delta \mu_{t}+\Delta \mu_{t}^{*}+\Delta p_{t}^{\prime}+\Delta y_{t}^{\prime}+\gamma_{t}$, and the model implies that $\beta_{0}=0$ and $\beta_{1}=1$. We estimated (13) by OLS, using our data from 1926:7 to 1933:2. The results of this estimation show that $\mathrm{Z}_{\mathrm{t}}$ exerts a significant positive effect on $\Delta \mathrm{G}_{\mathrm{t}} / \mathrm{s}_{\mathrm{t}} \overline{\mathrm{H}}_{\mathrm{t}} \cdot{ }^{15}$ The coefficient $\beta_{1}$, however, is significantly less than 1 . Our monthly data - - especially, the indexes for the rest-of-the-world variables - - are likely to involve substantial measurement errors and these errors could have biased the estimate of $\beta_{1}$ downwards.

It is also interesting to examine the behavior of $u_{t}$ over time. According to (9), $u_{t}$ represents a composite shock that includes not only shocks to money demand $\left(\Delta_{V_{t}}\right.$ and $\left.\Delta_{V_{t}}{ }^{*}\right)$ but also the influence of speculation and departures from uncovered interest parity (via $\Delta_{\mathrm{X}_{\mathrm{t}}}$ and $\Delta \varepsilon_{\mathrm{t}}$ ). Figure 3 shows the values of $\mathrm{u}_{\mathrm{t}}$ from 1926:7 to 1933:2, estimated from (13) with the

of the world less the US is 55 percent (League of Nations, various issues).

${ }^{15}$ Estimates of the regression are as follows:

$$
\Delta \mathrm{G}_{\mathrm{t}} / \mathrm{s}_{\mathrm{t}} \overline{\mathrm{H}}_{\mathrm{t}}=0.002+0.546 \mathrm{z}_{\mathrm{t}}+\mathrm{u}_{\mathrm{t}} \text {, }
$$

$\mathrm{R} 2=0.179$, standard error of regression $=0.020, \mathrm{DW}$ Statistics $=1.516,(\mathrm{t}-\mathrm{values}$ in parentheses $)$ 
constraint (implied by the model) that $\beta_{0}=0$ and $\beta_{1}=1$. During the early 1930s (the period relevant to our counterfactuals discussed below), Figure 3 shows large negative values of $u_{t}$ for the months of October 1931, June 1932, and February 1933. One possible explanation of the three large negative residuals is that they were caused by speculative attacks (resulting from shifts in $x_{t}$ ). If speculative attacks did occur, it is interesting to examine what the source of these attacks was and how dollar speculation would have been influenced by our counterfactuals. We explore these questions below. However, since the historical evidence (discussed in section 2) that speculative attacks occurred is not compelling, we also consider the possibility that the three residuals were produced by large exogenous shocks that would not have been affected by our counterfactuals.

To explore the role of dollar speculation, we first consider a first-generation speculative attack model, which assumes that the US would have left the gold standard if the $\mathrm{G}_{\mathrm{t}} / \mathrm{H}_{\mathrm{t}}$ ratio fell to some critical level, $\phi$ (e.g., determined by legal reserve requirements). Following the approach of Flood and Garber (1984) and Blanco and Garber (1986), we develop such a model for our large-country case in Appendix 1. A critical variable in this model is the shadow exchange rate -that is, the hypothetical exchange rate that would prevail (under permanently flexible exchange rates) if US gold reserves fell to the critical level, $\phi H_{t}$. This rate evolves as a function of US excess reserves $\left(G_{t}-\phi H_{t}\right)$ and relative levels of US money multiplier, output and prices (i.e., $\mu_{t}-\mu_{t}^{*}, y_{t}-y_{t}^{*}$, and $\left.p_{t}-p_{t}^{*}\right)$. The probability of US devaluation equals the probability that the shadow exchange rate exceeds the actual exchange rate.

According to our estimates (discussed in Appendix 1), the predicted value of the shadow exchange rate for October 1931 was much below the actual exchange rate and implied almost zero probability of US devaluation in that month. The shadow exchange rate rose in response to 
large gold outflows in October 1931 and then June 1932, but its predicted value stayed sufficiently below the actual exchange rate to imply a negligible likelihood of US devaluation even in February 1933. Thus, if there were speculative attacks in the three critical months, this model is not able to explain the attacks.

An approach based on second-generation models seems more promising in explaining why speculative attacks may have occurred. As discussed by Flood and Marion (1997), the commitment to a fixed exchange rate in the "second-generation models" is not state invariant but can depend on a number of state variables. To incorporate this feature in our model in a simple way, we consider $\phi$ a variable (instead of a constant), which is potentially a function of factors that could have influenced the U.S. commitment to the gold standard. An upward shift in $\phi$ would raise the shadow exchange rate (by decreasing $G_{t}-\phi H_{t}$ ) and hence could lead to an increase in $\mathrm{x}_{\mathrm{t}}$. Using this approach, speculation in the three critical months could be attributed to a combination of worsening economic conditions and certain events. A speculative attack in October 1931, for example, might have been triggered by the UK devaluation in September 1931, which weakened the international commitment to the gold standard, and could have suggested a weakening of the US resolve to adhere to the gold standard during a depression. Actions by the US Congress and the Federal Reserve from March through June 1932 might have signaled a shift in policy and lead to another attack in June 1932. Finally, speculation against the US dollar in February 1933 could have resulted from the internal drain in that month and the expectation that the Roosevelt administration would abandon the gold standard in an effort to check the deepening depression.

The Federal Reserve could have undertaken expansionary monetary policy, as represented 
by (10), at different stages of the Great Depression. ${ }^{16}$ A critical time for the pursuit of such a policy was the onset of the first banking crisis in October 1930. Therefore, we first consider a counterfactual in which expansionary policy is initiated in this month. It is often thought that the gold standard became a much more important constraint on US monetary policy after the UK devaluation. ${ }^{17}$ We thus also consider a second counterfactual in which expansionary policy is implemented in September 1931. For each counterfactual, we start with a number of plausible assumptions about the behavior of key variables, and later explore the sensitivity of our results to variations in these assumptions.

\subsection{Counterfactual 1: Expansionary Policy, October 1930-February 1931}

Our basic assumption is that if the Federal Reserve had increased domestic credit sufficiently in response to the first wave of banking panics, subsequent banking panics would have been averted. Although it is difficult to determine the precise amount of change in domestic credit that would have been adequate to restore confidence in the banking system, we suppose that a $\$ 1$ billion increase in domestic credit from October 1930 to February 1931 (instead of an actual decrease of $\$ 37$ million over this period) would have been more than enough for this purpose. ${ }^{18}$ Domestic credit expansion of this magnitude would have easily met the need for additional bank reserves and more than offset the money-supply effect of the decrease in the money multiplier

\footnotetext{
${ }^{16}$ Such knowledge was available and was used in the 1920s, by Benjamin Strong to conduct open market operations to smooth economic activity, to maintain price stability, and to prevent banking panics. This knowledge could have been utilized by his successors to mitigate the deflationary experience of the Great Depression and to prevent its transmission to the rest of the world.

${ }^{17}$ See, for example, Romer (1993). Eichengreen (1992) also focuses on this period in discussing the gold-standard constraint for US monetary policy.

18 Open market operations of similar amounts are suggested by Friedman and Schwartz (1963) for the first eight months of 1930 or the first six months of 1931. In our counterfactual, we set $\delta_{t}^{b}$ equal to $\$ 200$ million from October 1930 to February 1931 and $\delta_{t}^{n}$ equal to - \$10 million from March 1931 to February 1933 . These values yield a rate of money growth (M2) of about $2.4 \%$ over the simulation period, which is approximately equal to the growth rate in the presimulation period.
} 
during the crisis. Furthermore, if the open market purchase had been directed to the provision of bank reserves, there would have been no direct offset on free gold. ${ }^{19}$ We expect that under this policy, the money multiplier would have started recovering by March 1931 and then move gradually towards its normal level. We use the following model to simulate the time path of the multiplier (in logs) from 1931:3 to 1933:2:

$$
\mu_{t}=a\left(\bar{\mu}-\mu_{t-1}\right)+\mu_{t-1},
$$

where $\bar{\mu}$ is the average value of $\mu_{t}$ for the pre-crises period 1926:7-1930:9. The speed of adjustment towards this normal level $\bar{\mu}$ depends on the parameter $a$, and we initially set it equal to a conservative value of 0.1 . (See Figure 4 for the path of $\mu_{t}$ generated by this model).

We also assume that by restoring financial stability and arresting the decline in the money stock, the expansionary policy would have significantly reduced the severity of the Depression in the US as well as the rest of the world. This assumption has a number of implications. First, the UK would not have devalued in September 1931 and there would have been no reason for speculation that the US dollar might be devalued (hence $\mathrm{x}_{\mathrm{t}}$ would equal zero). We assume that the three large negative $u_{t}$ shocks for October 1931, June 1932 and February 1933, which could be attributed to speculation, would not have occurred in this case.

In our simulation, we thus set $u_{t}$ (as estimated in Figure 3) equal to zero for these three months but otherwise assume no change in the behavior of $u_{t}$. Second, if the UK had not devalued and devaluation by the US not have been feared, it is likely that France would not have accelerated conversion of dollar claims into gold reserves that it sterilized accompanied by a

\footnotetext{
${ }^{19}$ However, there would have been a small indirect effect, to the extent that member banks reduced their borrowing, and hence eligible paper would have declined.
} 
significant decrease in its domestic credit after September $1931 .{ }^{20}$ We assume that the average change in French domestic credit for the 1931:10-1933:2 period would have been the same as it was in the 1926:7-1931:9 period, and we adjust the mean of the series on French domestic credit (for the post-devaluation period) accordingly in calculating $\Delta \mathrm{D}^{*}$. Finally, since the US experienced a worse contraction than other countries, especially the countries (such as the UK) that left the gold standard in 1931, we would expect the expansionary policy to have brought about a stronger improvement in US economic activity relative to the rest of the world. Consequently, we assume that from 1931:3 to 1933:2, $\Delta p_{t}^{\prime}$ and $\Delta y_{t}^{\prime}$ both equal their mean rate of change for the pre-crises 1926:7-1930:9 period.

Given these assumptions, we use (9)-(12) to construct the smooth money counterfactual 1. The main results of this counterfactual are presented in Figures 5 and 6 . Figure 5 shows that gold reserves under counterfactual 1 fall after the first banking crisis and again after UK devaluation, reaching their lowest level in July 1932. However, even at their lowest level, simulated gold reserves are only about $\$ 100$ million less than the actual stock. The behavior of the gold-reserve ratio under counterfactual 1 is shown in Figure 6. After falling sharply during the domestic credit expansion up to February 1931, this ratio stabilizes until August 1932 and increases moderately afterwards. The ratio stays above 54 percent throughout the simulation period, and thus there would clearly have been an adequate supply of free gold -- that is, gold not required for the backing of eligible liabilities -- under counterfactual 1.

We performed a large number of simulations to explore the sensitivity of our results to variations in assumption regarding: (1) the behavior of the multiplier, (2) French policy, and (3)

\footnotetext{
${ }^{20}$ Of the three countries, the average value of domestic credit change decreased significantly after the UK devaluation only in the case of France.
} 
relative US macroeconomic performance (i.e., the behavior of $\Delta y_{t}^{\prime}$ and $\Delta p_{t}^{\prime}$ ). We also considered the possibility that the three large negative residuals represent exogenous shocks and would not have been eliminated under expansionary policy. The results of this analysis are summarized in the Sensitivity Appendix 2. The analysis shows that even under the most unfavorable assumptions, the gold-reserve ratio stays well above 50 percent in counterfactual 1.

\subsection{Counterfactual 2: Expansionary Policy, September 1931- January 1932}

We assume that the Federal Reserve increases domestic credit by about an additional billion dollars from September 1931 to January $1932 .^{21}$ Expansion of domestic credit by an extra billion dollars would have allowed high-powered money to increase by more than the actual increase in the public's holding of currency and would have considerably eased the pressure on bank reserves. It is thus plausible to suppose that the money multiplier would have recovered after some lag, perhaps at a lower pace as compared to the first counterfactual. We assume that the multiplier would have fallen, as it actually did, up to December 1931 but that it would have started adjusting towards its normal level by January 1932. We again use model (14) to simulate the behavior of the multiplier but assume a more conservative value of .025 for the adjustment parameter, $a$. We would also expect some improvement in relative US economic performance under this counterfactual. We assume that this improvement takes place by the beginning of 1932, and starting January 1932 , set both $\Delta p_{t}^{\prime}$ and $\Delta y_{t}^{\prime}$ equal to their average rates for the 1926:07-1931:09 period (which are lower than the corresponding rates assumed in the first

\footnotetext{
21 A similar counterfactual is discussed by Friedman and Schwartz (1963). In our simulation, we assume the following values of $\delta_{t}^{b}$ from September 1931 to January 1932 to ensure that high-powered money exceeds the actual increase in currency held by public in each month: 250 in 1931:9, 1250 in 1931:10, 250 in 1931:11, 0 in 1931:12 and 150 in 1932:1. The assumed increase in domestic credit over this period exceeds the actual increase by about $\$ 1050$ million. For the remaining simulation period, $\delta_{\mathrm{t}}^{\mathrm{n}}$ is set equal to 0 to produce almost a zero rate of money growth of the presimulation period.
} 
counterfactual).

It is less clear what effect counterfactual-2 expansionary policy would have had on possible speculation against the dollar. As discussed above, a plausible explanation of dollar speculation is that it resulted essentially from worsening economic conditions. To the extent that this policy would have improved economic conditions, it would have been seen as strengthening the US commitment to gold and thus would have caused less speculation. We assume nevertheless that this policy would not have reduced possible dollar speculation in October 1931 or changed French policy reaction. Therefore, for counterfactual 2 , we do not change the $u_{t}$ shock for October 1931 or adjust the time path of French domestic credit. However, we assume that improved economic performance resulting from the policy would have precluded further speculation against the US dollar and set (as in counterfactual 1) the $u_{t}$ shocks for June 1932 and February 1933 equal to zero.

The behavior of gold reserves and the gold-reserve ratio under counterfactual 2 is also shown in Figures 5 and 6. In this counterfactual, both gold reserves and the gold-reserve ratio would have declined sharply during the nine months after the UK devaluation, falling to their lowest values in July 1932. Even at this critical stage, however, gold reserves would have been only about $\$ 750$ million below their actual level and the gold-reserve ratio still above 42.5 percent. Counterfactual 2 would, therefore, not have posed a serious problem for the US to stay on the gold standard.

The results for our second counterfactual differ significantly from Eichengreen's (1992, pp. 295-6) estimate that a policy designed to offset the decline in the stock of (M1) money from August 1931 to January 1932 would have decreased US gold reserves by $\$ 2$ billion and forced the US off the gold standard. His calculations ignore the role of the money multiplier [see Bordo (1994)], and do not use a model to determine gold flows. Nevertheless, his estimate differs from 
ours largely because he considers a different policy. Our counterfactual is based on a policy, similar to the one suggested by Friedman and Schwartz (1963), which focuses on the need for an adequate domestic-credit expansion to respond to the banking crises but does not require the money stock to stay at the initial level. Indeed, the (M2) money stock in our simulation falls from September 1931 to July 1932 but then increases gradually up to February 1933 to reach a level only about $\$ 300$ million below its initial value. The Eichengreen experiment, on the other hand, involves offsetting the August 1931 to January 1932 decline in the money stock over a short period and hence requires a much bigger expansion in domestic credit. ${ }^{22}$ In our view, if the Federal Reserve had acted only after the UK devaluation, an expansionary program of the order of magnitude assumed in our counterfactual [and suggested by Friedman and Schwartz (1963)] would have been appropriate at this late stage. Such a program would have improved economic conditions without driving the US off the gold standard.

We also explored the sensitivity of the results of counterfactual 2 to a number of variations. Our discussion below focuses on key variations (see Sensitivity Appendix 2 for other variations and other details). An interesting issue is that counterfactual 2 may not have been credible and, like the open market operations from March through June 1932, may in fact have induced further speculation. To explore this possibility, we set the $u_{t}$ shock for October 1931 equal to the sum of the actual residuals for both October 1931 and June 1932. This variation of counterfactual 2 lowers the path of the gold-reserve ratio, but the ratio still stays above 41.5 percent. However, the large gold outflow in October 1931 (induced by the bigger $\mathrm{u}_{\mathrm{t}}$ shock) would now lower the path of $\mathrm{H}_{\mathrm{t}}$ (as well as $\mathrm{M}_{\mathrm{t}}$ ). We thus consider another variation in which domestic credit is increased by another $\$ 300$ million in October 1931 to keep the path of $\mathrm{H}_{\mathrm{t}}$

\footnotetext{
${ }^{22}$ Using our model, for example, we calculate that an increase in domestic credit of about 2300 million dollars (in addition to the actual increase from September 1931 to January 1932) would have been needed to raise the stock of
} 
roughly the same as in our basic counterfactual. The gold-reserve ratio in this variant (which combines a bigger shock with a greater injection of domestic credit) falls at its lowest level to 38.6 percent. If a slower recovery is also assumed, the lowest value of the ratio would be further reduced to 38.3 percent. The statutory requirement, which was a weighted average of the 40 percent requirement for currency and the 35 percent requirement for deposits at the Federal Reserve, depending on the relative shares of currency and deposits was about 37 percent in October 1931 (the actual weighted average was 62.6 percent). The statutory requirement would not have been breached.

It should be emphasized that our simulation assumes the case of perfect or near-perfect capital mobility (i.e., considers $u_{t}$ exogenous to domestic-credit policy), which implies a high offset coefficient (equal to the rest-of the-world share in world high-powered money). There were likely significant departures from this assumption, especially after the UK devaluation which led to a wide range of restrictions on international capital flows. Austria, Germany, and Hungary instituted capital controls in the summer of 1931. The UK and the sterling area introduced controls at the end of 1931, as did Japan in 1932. Thus, the estimate of gold loss resulting from domestic credit expansion in our second counterfactual is likely to be overstated.

Our estimates omit a significant portion of the rest of the world. To explore the bias resulting from this omission, we modified our basic simulations to increase the size of $\overline{\mathrm{H}}_{\mathrm{t}}^{*}$ such that the aggregate high-powered money for UK, France and Germany is always 60 percent of $\overline{\mathrm{H}}_{\mathrm{t}}^{*}$ (this percentage reflects the approximate share of the three countries in non-US world highpowered money based on the 21-country sample in Bordo and Eichengreen (1998b)). Holding other factors constant, we find that this adjustment decreases the gold-reserve ratio only slightly 
and does not alter the implications of our results for the feasibility of expansionary money. ${ }^{23}$

\section{Conclusions}

The recent consensus view is that the gold standard is the key cause of the Great

Depression. This view has merit, first in the sense that deflationary shocks were transmitted by the gold standard and, second, in the sense that for most countries continued adherence to gold blocked their recoveries. These were small, open economies, with limited gold reserves. This was not, however, the case for the US. The US was the largest country in the world, held massive gold reserves, and hence was not constrained from using expansionary policy to offset banking panics. Indeed, under Benjamin Strong, the Federal Reserve had demonstrated its ability to pursue such policies.

This conclusion holds even in the face of perfect international capital flows. Dollar claims against the US were minor relative to the size of its gold reserves in contrast with the situation today. Emerging countries that recently experienced crises hold outstanding international liabilities far in excess of their international reserves. This made it hard for them to alleviate domestic banking difficulties using domestic monetary policy.

The simulations we constructed, based on a model of a large open economy, indicate that expansionary open market operations at two critical junctures of the Great Depression would have been successful in averting the banking panics without endangering convertibility. Indeed, had expansionary open market purchases been conducted in 1930, the Depression would not have led to the international crises that followed.

\footnotetext{
${ }^{23}$ The adjustment in $\overline{\mathrm{H}}_{\mathrm{t}}^{*}$ affects $\mathrm{s}_{\mathrm{t}}$ and [via (13)] $\mathrm{u}_{\mathrm{t}}$. We assume that the behavior of $\Delta D_{t}^{*}, \Delta \mu_{t}^{*}, \Delta p_{t}^{\prime}$ and $\Delta y_{t}^{\prime}$ is unchanged.
} 
Figure 1. Gold Reserves (US Dollars), 1928-33, Monthly

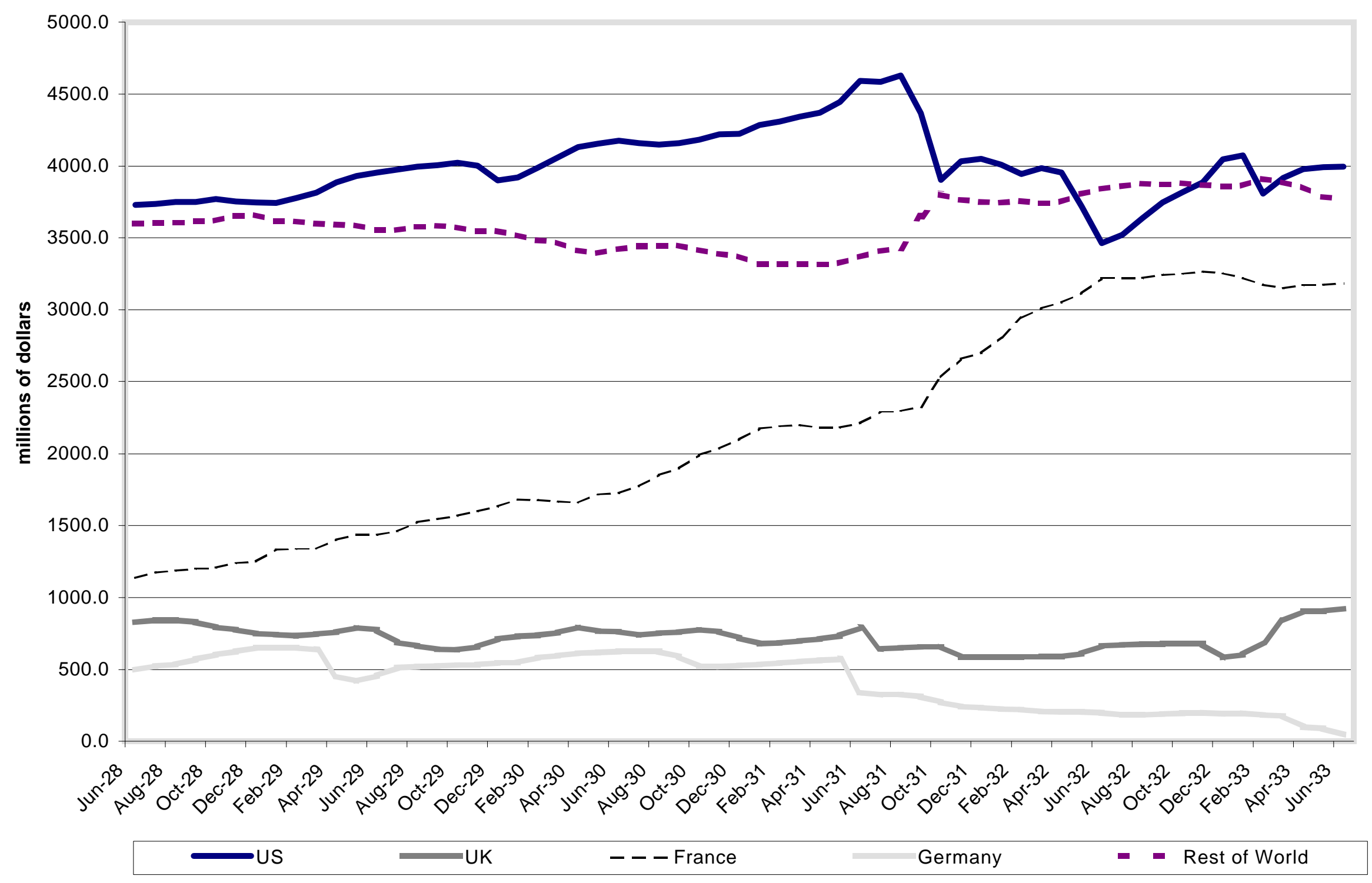


Figure 2. Gold Reserves (Shares), 1928-33, Monthly

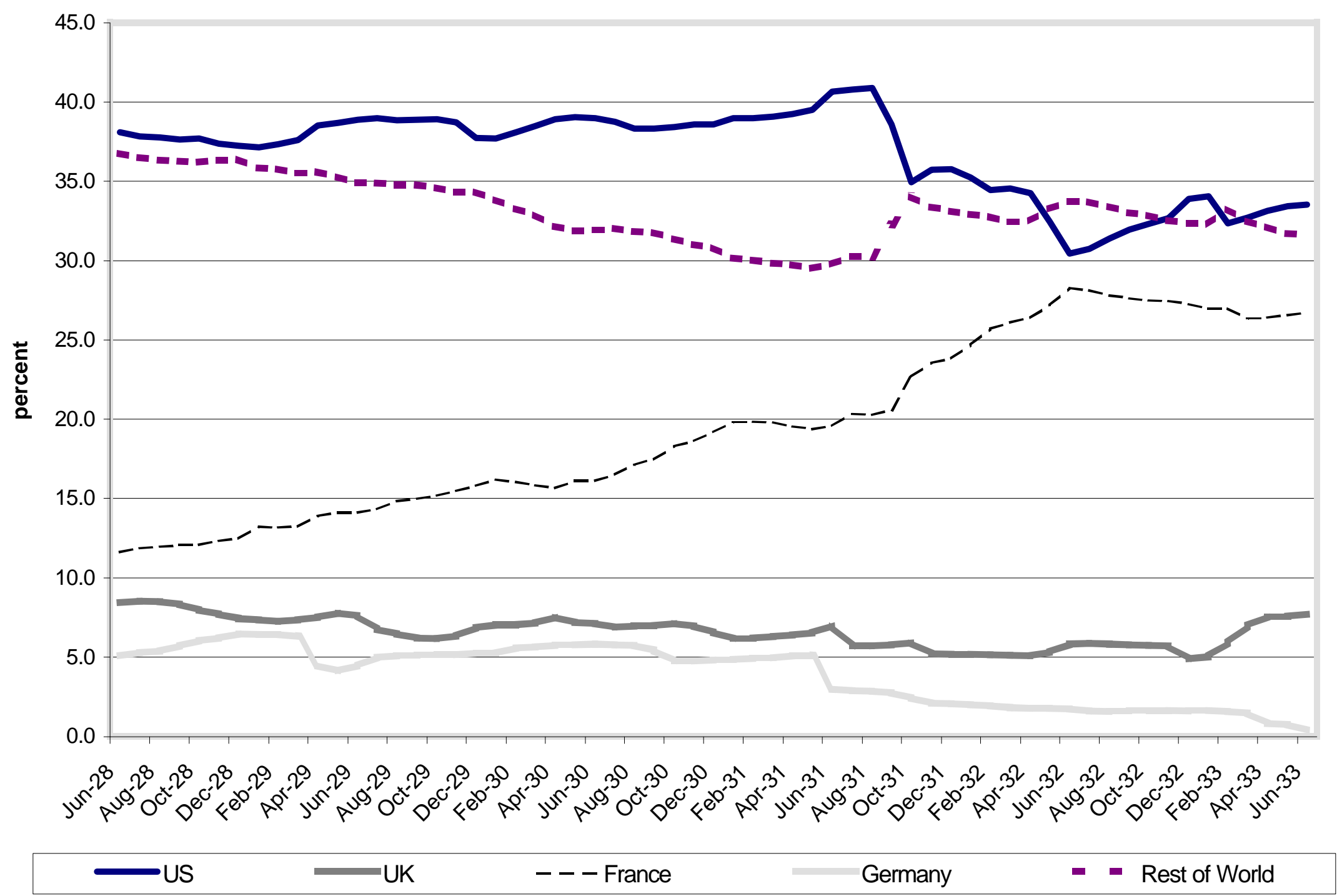


Figure 3

The Behavior of the Residual $u_{t}, 1925: 05-1933: 02$

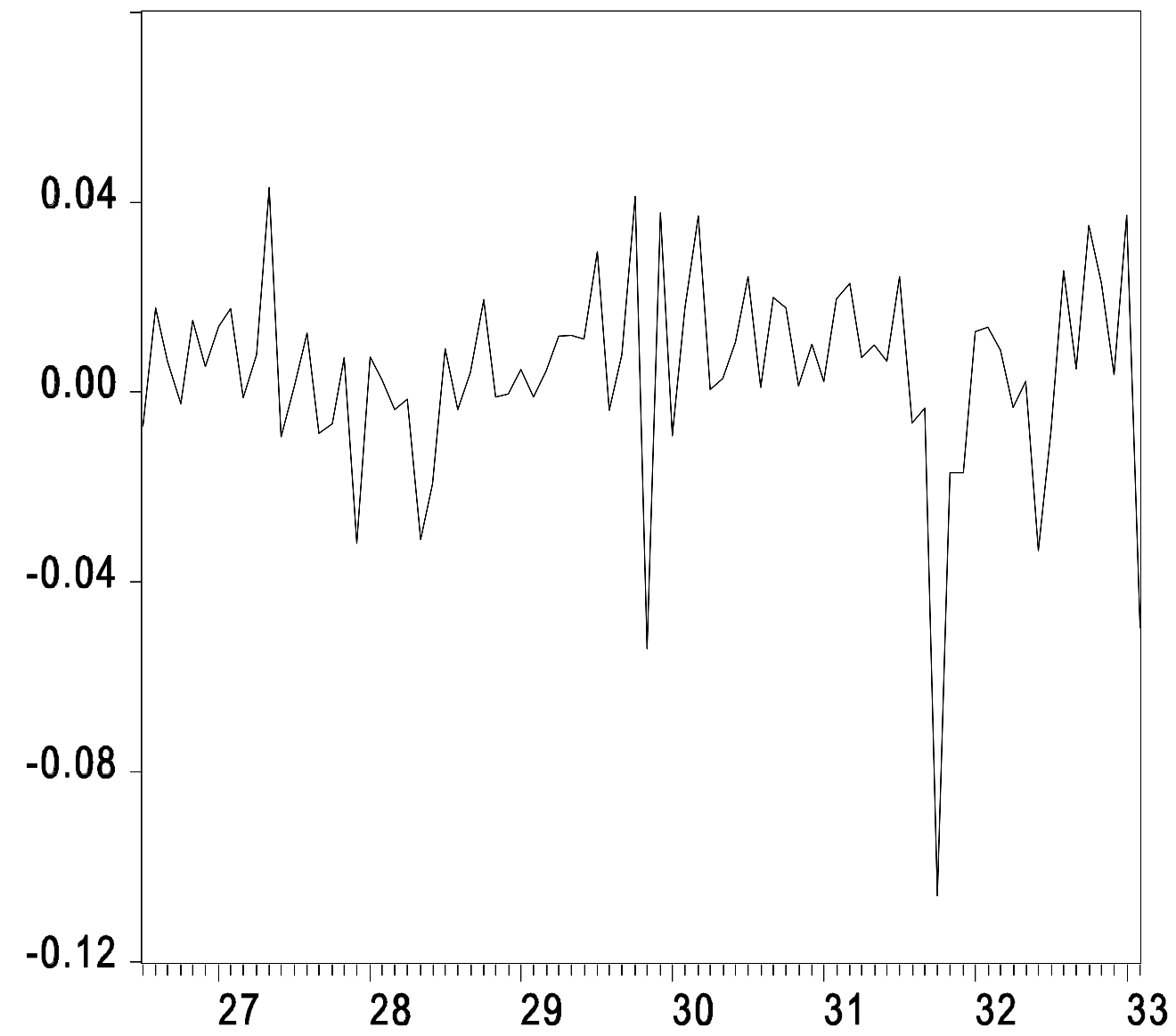




\section{Figure 4}

The Actual and Simulated Values of the Money Multiplier (in logs), 1926:07-1933:02

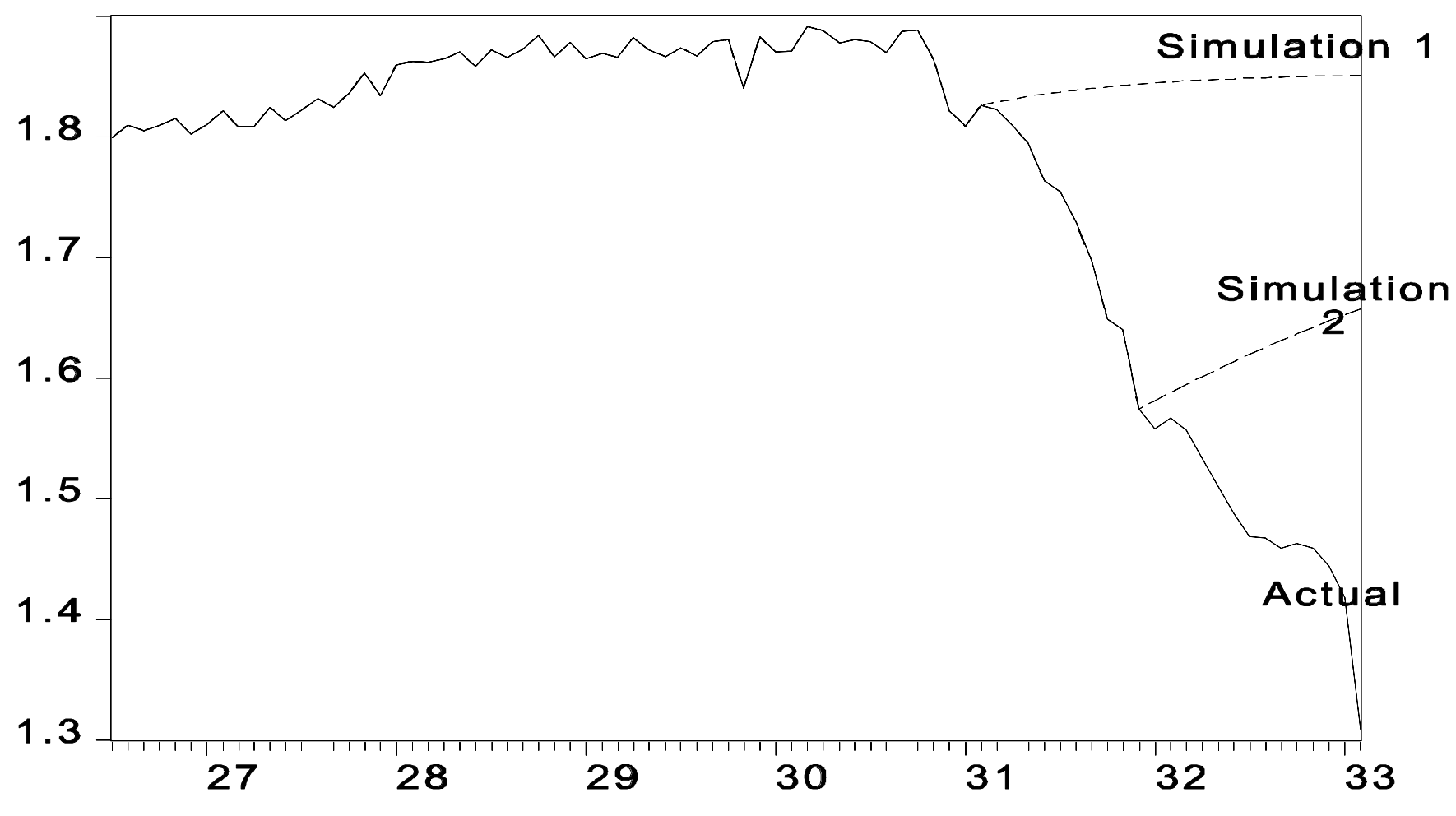


Figure 5

The Actual and Simulated Values of US Gold Reserves (million dollars)

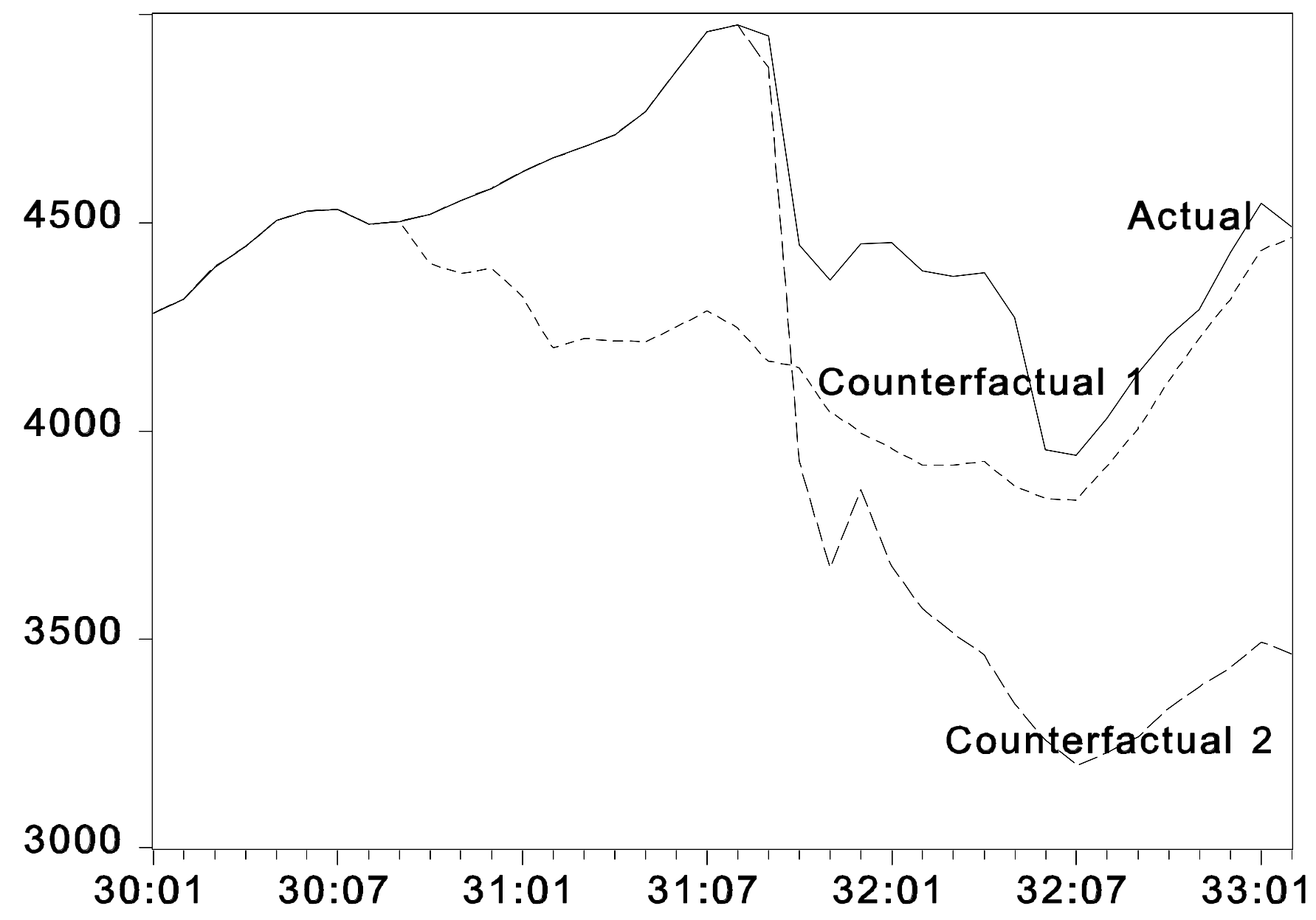


Figure 6

The Actual and Simulated Values of US Gold-Reserve Ratio

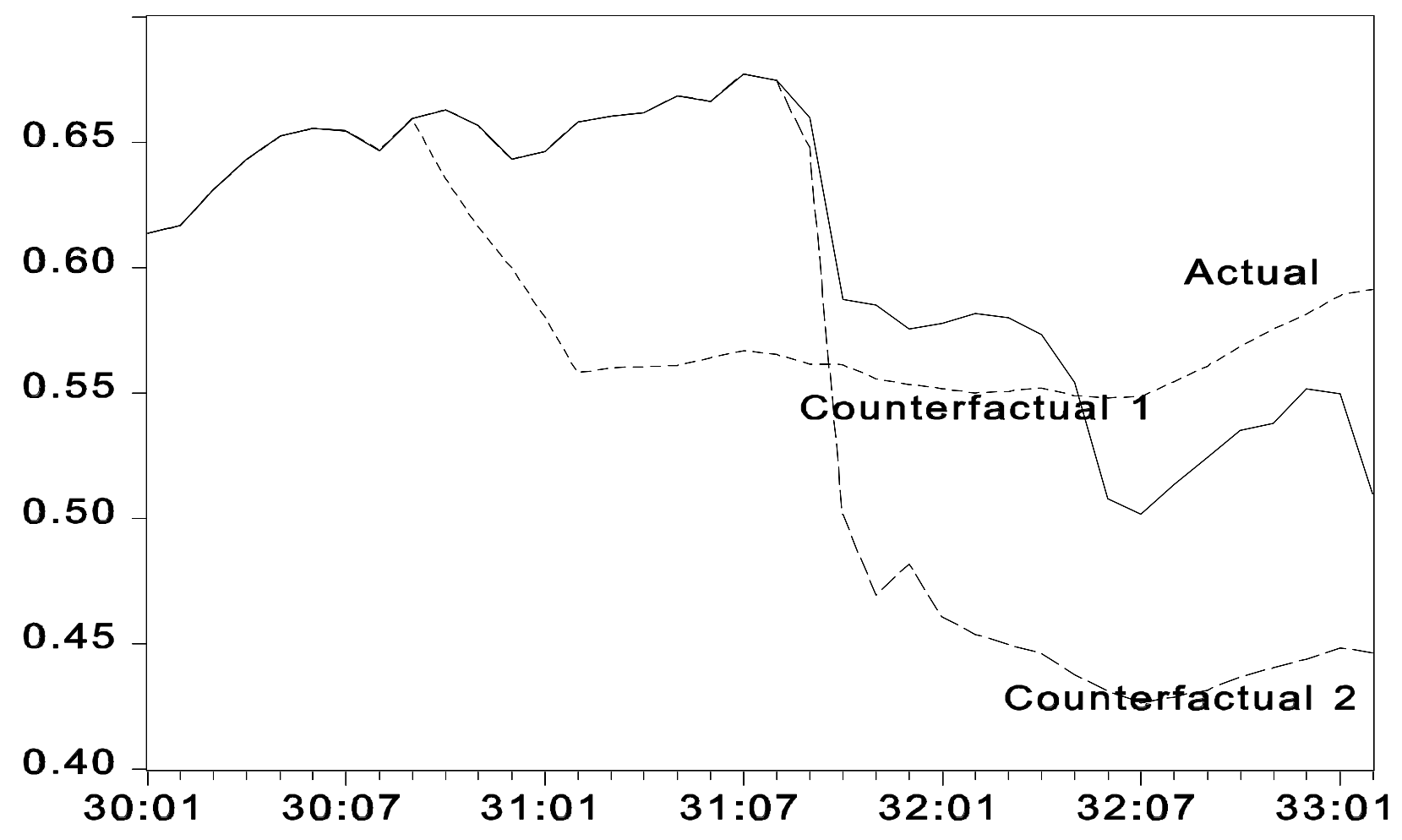




\section{Data Appendix}

Monthly US, UK, French, German, and rest of world gold reserves in Figures 1 and 2 come from Federal Reserve (1943).

Monthly data for UK, France, Germany and US used in section 4 are from the database developed by Kwiecinska-Kalita [see her (1995) thesis for detailed description and sources of these data]. Money supply series are based on an M3 definition of money for UK, M2 for US and Germany, and M1 for France (time and saving deposits for France are not available for the whole period). The money supply and high-powered money data for the US are the same as in Friedman and Schwartz (1963) and are already seasonally adjusted. These data for other countries were seasonally adjusted using a procedure based on moving averages. Domestic credit was defined as the difference between high-powered money and gold reserves. Gold reserve monthly data for France are available only since June 1928. French gold reserves before this date were estimated using the assumption that they were a fixed proportion of French high-powered money. Price level and output for each country were measured by indexes of consumer (retail) prices and industrial production. These indexes were smoothed using the Hodrick-Prescott filter with the smoothing parameter equal to 14400 .

\section{References}

Federal Reserve, Banking and Monetary Statistics, 1914-1941, p. 544.

Kwiecinska-Kalita, Helena, "Monetary Independence Under a Fixed Exchange Rate: The Interwar Experience, 1925:5-1931:4", Ph. D. Thesis, University of Toronto, 1995. 


\section{Appendix 1: A First Generation Model of Speculative Attack Against the US Dollar}

We use (1)-(3), its foreign counterparts and (7), and let $\alpha_{1}=\alpha_{1}^{*}=1, \alpha_{2}=\alpha_{2}^{*}$ to obtain the following basic relation:

$$
p_{t}^{\prime}=\log \left(H_{t} / H_{t}^{*}\right)+\mu_{t}^{\prime}-\alpha_{0}^{\prime}-y_{t}^{\prime}-\alpha_{2}\left(x_{t}+\varepsilon_{t}\right)-v_{t}^{\prime},
$$

where a prime denotes the difference between US and foreign values (e.g., $p_{t}^{\prime}=p_{t}-p_{t}^{*}$ ).

We can also express

$$
\text { (A2) } p_{t}^{\prime}=s_{t}+\eta_{t} \text {, }
$$

where $s_{t} \equiv \log \left(e_{t}\right)$ and $\eta_{t}$ is the deviation from the purchasing power parity. Letting $\bar{e}$ denote the fixed value of the exchange rate under the gold standard, we set $\bar{e}=1$ (and thus, $\bar{s} \equiv \log (\bar{e})=0$ ) by choice of units. With this normalization, $\eta_{t}=p_{t}^{\prime}$ under fixed exchange rates according to (A2).

Assume that there was a critical ratio $\phi$ such that if US gold reserves reached the level $\phi H_{t}$, the US would have left the gold standard and let the dollar float. Let $\tilde{s}_{t}$ represent the shadow value of $s_{t}$, which would have materialized if the US lost reserves equal to $G_{t}-\phi H_{t}$ at time t. Using (A1) and (A2) and letting $x_{t}=E_{t} \tilde{s}_{t+1}-\tilde{s}_{t}$, we obtain

$$
\left(1-\alpha_{2}\right) \tilde{s}_{t}=R_{t}-\alpha_{2} E_{t} \tilde{s}_{t+1}
$$

where

$$
R_{t} \equiv \log \left[\left(D_{t}+\phi H_{t}\right) /\left(D_{t}^{*}+G_{t}^{*}+G_{t}-\phi H_{t}\right)\right]+\mu_{t}^{\prime}-\alpha_{0}^{\prime}-y_{t}^{\prime}-v_{t}^{\prime}-\alpha_{2} \varepsilon_{t}-\eta_{t} .
$$

Note that we use the fixed exchange rate $(=1)$ to convert US gold reserves into foreign reserves since speculators would have purchased US gold at the pre-float price and then sold it to the rest 
of the world at the foreign price.

Suppose that the stochastic process for $R_{t}$ is

$$
R_{t}=\rho_{0}+\rho_{1} R_{t-1}+\xi_{t}
$$

where $\xi_{t}$ is a white noise shock with standard deviation equal to $\sigma$. Solving (A3) and (A5), we get

$$
\tilde{s}_{t}=-\alpha_{2} \rho_{0} \psi+\psi R_{t}
$$

where $\psi=1-\alpha_{2}+\alpha_{2} \rho_{1}$. Note that (A4) and (A6) imply that $\tilde{s}_{t}$ increases in $G_{t}-\phi H_{t}$ and $\mu_{t}^{\prime}$, and decreases in $y_{t}^{\prime}$ and $\eta_{t}$. Let $\pi_{t}$ denote the probability of US devaluation at time $t$ based on information at time $t-1$. Using (A5) and (A6), we have $\pi_{t}=\operatorname{prob}\left(\tilde{s}_{t}>0\right)=\operatorname{prob}\left(\xi_{t}>-E_{t-1} R_{t} / \psi\right)$, and $x_{t}=\pi_{t} E\left(\tilde{s}_{t} \mid \xi_{t}>-E_{t-1} R_{t} / \psi\right)$.

To simplify the estimation of $R_{t}$, we ignore shocks to money demand and deviations from interest parity and let $v_{t}^{\prime}=\varepsilon_{t}=0$. We also assume that gold parities were not expected to change initially and let $x_{t}=0$ for the initial period 0 . Then setting $t=0$ in (A1), we obtain $\alpha_{0}^{\prime}=\log \left(H_{0} / H_{0}^{*}\right)+\mu_{0}^{\prime}-y_{0}^{\prime}-p_{0}^{\prime}$. Using this value of $\alpha_{0}^{\prime}$ and recalling that $\eta_{t}=p_{t}^{\prime}$ under fixed exchange rates, we can express (A4) as $R_{t}=\log \left[\left(D_{t}+\phi H_{t}\right) /\left(D_{t}^{*}+G_{t}^{*}+G_{t}-\phi H_{t}\right)\right]-\log \left(H_{0} / H_{0}^{*}\right)+\left(\mu_{t}^{\prime}-\mu_{0}^{\prime}\right)-\left(y_{t}^{\prime}-y_{0}^{\prime}\right)-\left(p_{t}^{\prime}-p_{0}^{\prime}\right)$.

We use this form to estimate $R_{t}$. We integrate our data on $\Delta \mu_{t}^{\prime}, \Delta y_{t}^{\prime}$ and $\Delta p_{t}^{\prime}$ (letting 1926:6 represent the initial period) to calculate the last three terms on the right hand side of the expression. 
Our estimation of (A5) yields $\rho_{0}=.004, \rho_{1}=1$ and $\sigma=.029$. Using these values, setting $\phi=$. $\alpha_{2}=-1$ initially, we show our estimates of $E_{t-1} \tilde{s}_{t}$ from 1930:1 to 1933:2 in Figure A1. This figure also shows bands representing margins equal to $\pm 2.9 \sigma$. The probability of $\tilde{s}_{t}$ falling outside these bands is less than .001 if $\xi_{t}$ is distributed normally. Up to October 1931, the value of $E_{t-1} \tilde{s}_{t}$ hovers around - .5, a level approximately $50 \%$ of the fixed rate $\bar{s}$ (equal to zero). The forecast increases sharply after large gold outflows in October 1931 and June 1932 but $\pi_{t}$ remains extremely low (as the upper band stays much below $\bar{s}$ ).

We considered higher-order AR processes for $R_{t}$ and different values of $\alpha_{2}$ but these variations had little effect on our results. A larger value of $\sigma \quad$ (e.g., because of the presence of $v_{t}^{\prime}$ and $\varepsilon_{t}$ shocks) or departures from normal distribution (e.g., fatter tails) could widen the .001 bands but such changes would still not be able to explain significant increases in $x_{t}$ for the three critical months. 
Figure A1

Predicted Value of $\tilde{s}\left(E_{t-1} \tilde{s}_{t}\right)$ and $\pm 2.9 \sigma$ Bands, 1930:1-1933:2

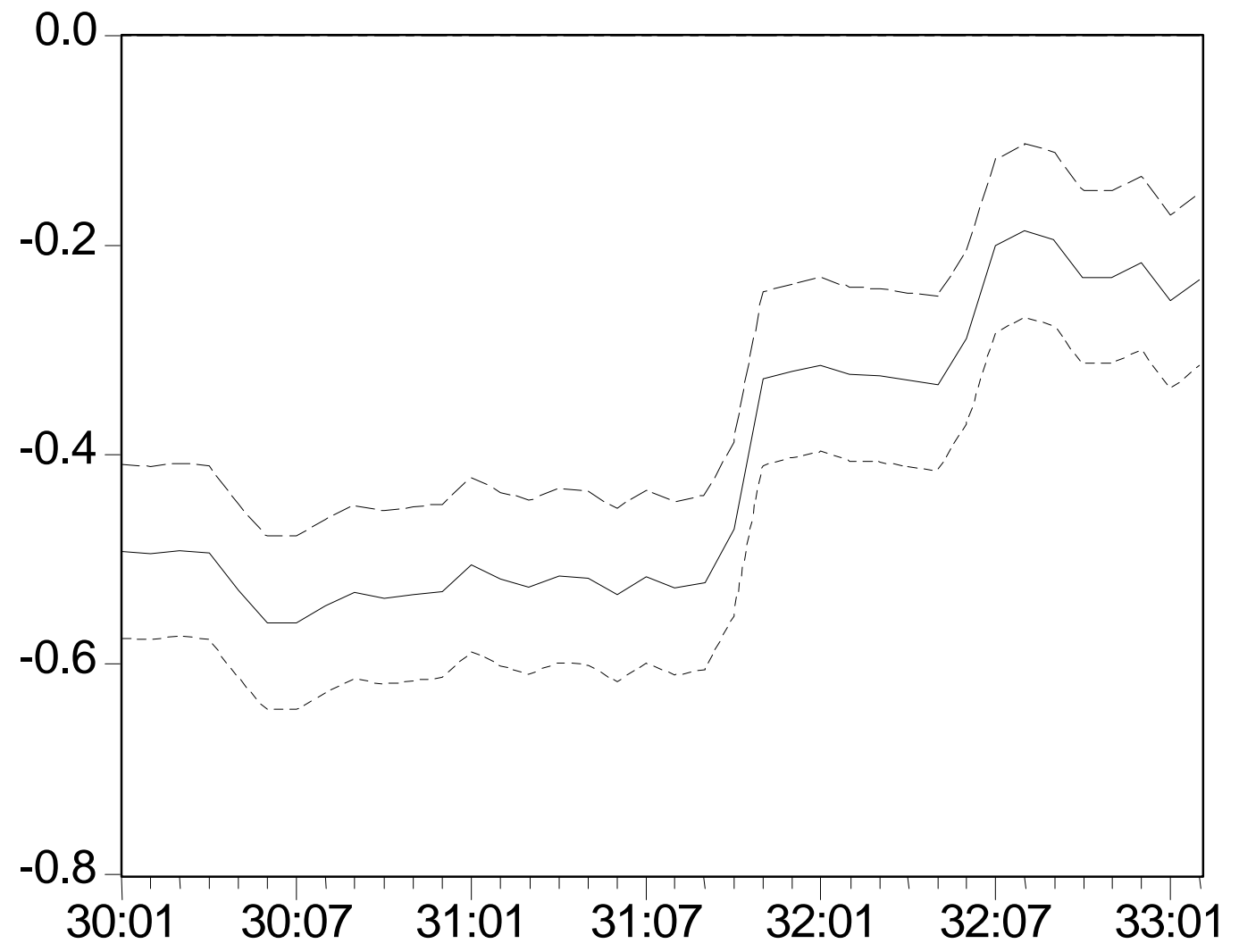




\section{SENSITIVITY APPENDIX 2}

The key results of our sensitivity analysis for the two counterfactuals are summarized in Tables A1 and A2. For a number of variations of the basic simulations, the tables show the lowest levels to which gold reserves and the gold-reserve ratio would have fallen during the simulation period.

Variations A-C in Table A1 modify the assumptions of the first counterfactual one at a time: Variation A considers a slower recovery of the money multiplier (from March 1931); Variation B assumes that French domestic credit policy after September 1931 would not have changed; and Variation $\mathrm{C}$ makes a more conservative assumption about the improvement in the relative performance of US output and prices. Variation D combines the unfavorable assumptions of variation B and C. Variation E explores the possibility that the three large negative residuals would not have been eliminated. Finally, variation $\mathrm{F}$ adjusts $\overline{\mathrm{H}}_{\mathrm{t}}^{*}$ according to the share of UK, France and Germany in the non-US world high-powered money but this adjustment does not much affect the results of the basic simulation. The table shows that the gold-reserve ratio stays well above 50 percent in all cases.

Variations of counterfactual 2 are shown in Table A2. These variations include the case of a larger shock in October 1931 (equal to the sum of October 1931 and June 1932 residuals) as well as the case that combines the larger shock with a more expansionary policy (involving an additional injection of $\$ 300$ million). The possibility that counterfactual 2 would not have affected any of the three residuals was also examined but this variation (not shown in the table) produces results similar to Variation B. 
Table A1

Sensitivity Analysis for Counterfactual 1

\begin{tabular}{|c|c|c|}
\hline & \multicolumn{2}{|c|}{ Lowest Simulated Values of } \\
\hline & $\begin{array}{l}\text { Gold Reserves } \\
\text { (mill. US \$) }\end{array}$ & $\begin{array}{l}\text { Gold-Reserve Ratio } \\
(\%)\end{array}$ \\
\hline $\begin{array}{l}\text { Basic Simulation } \\
\text { (as discussed in the text) }\end{array}$ & 3834 & 54.8 \\
\hline $\begin{array}{l}\text { Variation A } \\
\text { (slower recovery of the money multiplier) }\end{array}$ & 3859 & 55.0 \\
\hline $\begin{array}{l}\text { Variation B } \\
\text { (no change in French policy) }\end{array}$ & 3637 & 53.5 \\
\hline $\begin{array}{l}\text { Variation C } \\
\text { (slower recovery of US economy) }\end{array}$ & 3678 & 53.8 \\
\hline $\begin{array}{l}\text { Variation D } \\
\text { (variations B and C combined) }\end{array}$ & 3485 & 52.5 \\
\hline $\begin{array}{l}\text { Variation E } \\
\text { (three large residuals not eliminated) }\end{array}$ & 3306 & 51.1 \\
\hline $\begin{array}{l}\text { Variation F } \\
\text { (non-US high-powered money adjusted) }\end{array}$ & 3533 & 52.8 \\
\hline
\end{tabular}

Note: each variation differs from the basic simulation as indicated below.

Variation A: $a$ is set equal to .05 in (14) to determine $\Delta \mu$ from 1931:3.

Variation B: French domestic credit series not adjusted in calculating $\Delta \mathrm{D}_{\mathrm{t}}^{*}$.

Variation $\mathrm{C}: \Delta p_{t}^{\prime}$ and $\Delta y_{t}^{\prime}$ equal the average of their actual and simulated values.

Variation D: changes in Variations B and C combined.

Variation E: $u_{t}$ is not set equal to zero for 1931:10, 1932:6 and 1933:2.

Variation $\mathrm{F}$ : set $\overline{\mathrm{H}}_{\mathrm{t}}^{*}$ equal to 1.66 times the aggregate high-powered money of UK, France and Germany. 
Table A2

Sensitivity Analysis for Counterfactual 2

\begin{tabular}{lcc}
\hline & $\begin{array}{c}\text { Lowest Simulated Values of } \\
\text { Gold Reserves } \\
\text { (mill. US \$) }\end{array}$ & $\begin{array}{l}\text { Gold-Reserve Ratio } \\
(\%)\end{array}$ \\
\hline $\begin{array}{l}\text { Basic Simulation } \\
\text { (as discussed in the text) }\end{array}$ & 3196 & 42.6 \\
$\begin{array}{l}\text { Variation A } \\
\text { (constant money multiplier) }\end{array}$ & 3383 & 44.0 \\
$\begin{array}{l}\text { Variation B } \\
\text { (larger shock for October 1931) }\end{array}$ & 3060 & 41.6 \\
$\begin{array}{l}\text { Variation C } \\
\text { (larger shock, more expansionary policy) }\end{array}$ & 2892 & 38.6 \\
$\begin{array}{l}\text { Variation D } \\
\text { (slower recovery of US economy) }\end{array}$ & 3165 & 42.4 \\
$\begin{array}{l}\text { Variation E } \\
\text { (Variations C and D combined) }\end{array}$ & & 38.3 \\
$\begin{array}{l}\text { Variation F } \\
\text { (non-US high-powered money adjusted) }\end{array}$ & 3085 & 41.8 \\
\hline
\end{tabular}

Note: each variation differs from the basic simulation as indicated below.

Variation A: $\Delta \mu$ is set equal to zero from 1932:1.

Variation $B: u_{t}$ for 1931:10 set equal to the sum of 1931:10 and 1932:6 residuals.

Variation C: Variation B plus domestic credit increased by $\$ 300$ million.

Variation D: $\Delta p_{t}$ and $\Delta y_{t}$ equal the average of their actual and simulated values.

Variation E: changes in Variations $\mathrm{C}$ and $\mathrm{D}$ combined.

Variation $\mathrm{F}$ : $\overline{\mathrm{H}}_{\mathrm{t}}^{*}$ equals 1.66 times the aggregate high-powered money of $\mathrm{UK}$, France and Germany. 


\section{References}

Bernanke, Ben (1995). "The Macroeconomics of the Great Depression: A Comparative Approach," Journal of Money, Credit and Banking, 27 (February), 1-28.

Bernanke, Ben, and Harold James (1991). "The Gold Standard, Deflation, and Financial Crisis in the Great Depression: an International Comparison.” In R. G. Hubbard (ed.), Financial Markets and Financial Crises. Chicago: University of Chicago Press.

Blanco, Herminio and Peter M. Garber (1986). "Recurrent Devaluationand Speculative Attacks on the Mexican Peso."'Journal of Political Economy 94 (1) (February): 148-66.

Bordo, Michael D. (1994). "Review of Barry Eichengreen, Golden Fetters: The Gold Standard and the Great Depression," Journal of International Economics 36 (February), 193-197.

Bordo, Michael D., and Barry Eichengreen (1998a). "The Rise and Fall of a Barbarous Relic: The Role of Gold in the International Monetary System.” NBER Working Paper No. 6431.

Bordo, Michael D., and Barry Eichengreen (1998b). "Implications of the Great Depression for the Development of the International Monetary System.” In Bordo, Goldin and White (eds.) The Defining Moment: The Great Depression and the American Economy in the Twentieth Century. Chicago: Chicago University Press.

Brown, William A., Jr. (1940). The International Gold Standard Reinterpreted 1919-1934. New York: NBER, 2 vols.

Capie, Forrest, Terence C. Mills and Geoffrey E. Wood (1986). “What Happened in 1931?” In Forrest Capie and Geoffrey E. Wood (eds.) Financial Crises and the World Banking 
System. London: Macmillan, pp. 120-148.

Cassel, Gustav (1928). Postwar Monetary Stabilization. New York: Columbia University Press. Choudhri, Ehsan U., and Levis A. Kochin (1980). "The Exchange Rate and The International Transmission of Business Cycle Disturbances: Some Evidence from the Great Depression,” Journal of Money, Credit and Banking 12, pp. 565-574.

Cunliffe Report [1918] (1979). First Interim Report of the Committee on Currency and Foreign Exchanges after the War. Cmnd 9182. Reprint. New York: Arno Press.

Eichengreen, Barry (1992). Golden Fetters: The Gold Standard and the Great Depression, 19191939. New York: Oxford University Press.

Eichengreen, Barry (1990). Elusive Stability. New York: Cambridge University Press.

Eichengreen, Barry, and Olivier Jeanne (1998). "Currency Crisis and Unemployment: Sterling in 1931."

Eichengreen, Barry, and Jeffrey Sachs (1985). "Exchange Rates and Economic Recovery in the 1930's,” Journal of Economic History 45, pp. 925-946.

Einzig, Paul (1937). The Theory of Forward Exchange. London: Macmillan.

Flood, Robert P., and Peter M. Garber, "Collapsing Exchange Rate Regimes: Some Linear Examples", Journal of International Economics, 17 (August 1984), 1-13.

Flood, Robert P., and Nancy P. Marion (1996). "Speculative Attacks: Fundamentals and SelfFulfilling Prophecies.” NBER Working Paper No. 5789.

Friedman, Milton, and Anna J. Schwartz (1963). A Monetary History of the United States, 1867-1960. Princeton: Princeton University Press.

Hoover, Herbert (1952). The Memoirs of Herbert Hoover: The Great Depression 1929-1941. 
New York: Macmillan.

Howson, Susan (1980). "Sterling's Managed Float: The Operations of the Exchange Equalisation Account, 1932-39," Princeton Studies in International Finance No. 46 (November).

Johnson, H. Clark (1997). Gold, France, and the Great Depression, 1919-1932. Oxford: Oxford University Press.

Meltzer, Allan H. (1995). "Why Did Monetary Policy Fail in the Thirties?" A History of the Federal Reserve. Chapter 5, Carnegie Mellon (Mimeo).

Nurkse, Ragnar (1944). International Currency Experience. Geneva: League of Nations.

Romer, Christina (1993). "The Nation in Depression,” Journal of Economic Perspectives, 7 (Spring) pp.19-40.

Wigmore, Barrie (1987). "Was the Bank Holiday of 1933 Caused by a Run on the Dollar?" Journal of Economic History Vol. XLVII, No. 3 (Sept.) pp. 739-755.

Willis, H. Parker and John M. Chapman (1934). The Banking Situation. New York: Columbia University Press. 